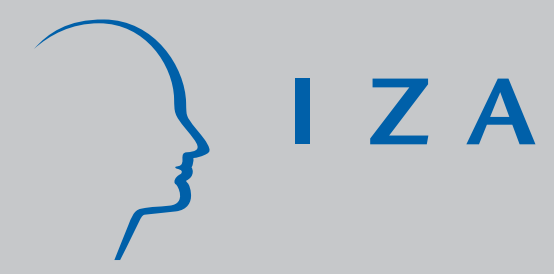

IZA DP No. 3695

The Impact of the Recent Expansion of the EU on the UK Labour Market

David G. Blanchflower

Helen Lawton

September 2008 


\title{
The Impact of the Recent Expansion of the EU on the UK Labour Market
}

\author{
David G. Blanchflower \\ Dartmouth College, University of Stirling, \\ NBER, CESifo, Bank of England and IZA
}

Helen Lawton

Bank of England

\section{Discussion Paper No. 3695 \\ September 2008}

\author{
IZA \\ P.O. Box 7240 \\ 53072 Bonn \\ Germany \\ Phone: +49-228-3894-0 \\ Fax: +49-228-3894-180 \\ E-mail: iza@iza.org
}

\begin{abstract}
Any opinions expressed here are those of the author(s) and not those of IZA. Research published in this series may include views on policy, but the institute itself takes no institutional policy positions.

The Institute for the Study of Labor (IZA) in Bonn is a local and virtual international research center and a place of communication between science, politics and business. IZA is an independent nonprofit organization supported by Deutsche Post World Net. The center is associated with the University of Bonn and offers a stimulating research environment through its international network, workshops and conferences, data service, project support, research visits and doctoral program. IZA engages in (i) original and internationally competitive research in all fields of labor economics, (ii) development of policy concepts, and (iii) dissemination of research results and concepts to the interested public.
\end{abstract}

IZA Discussion Papers often represent preliminary work and are circulated to encourage discussion. Citation of such a paper should account for its provisional character. A revised version may be available directly from the author. 
IZA Discussion Paper No. 3695

September 2008

\section{ABSTRACT \\ The Impact of the Recent Expansion of the EU on the UK Labour Market}

We examine the impact on the UK of the influx of workers from Eastern Europe. We look at the characteristics of the workers who have come to the UK since 2004. We also use data from a number of Eurobarometers 2004-2007 as well as the 2005 Work Orientation module International Social Survey Programme to look at the attitudes of residents of these countries. East Europeans report that they are unhappy with their lives and the country they live in, are dissatisfied with their jobs and would find difficulties in finding a new job or keeping their existing job. Relatively high proportions express a desire to move abroad. Expectations for the future for both their economy and their personal situations remain low but have improved since 2004. There has been some deterioration in the availability of jobs in the UK economy as the economy moves into recession. The UK is an attractive place to live and work for these workers. We argue that rather than dissipate, flows to the UK could remain strong well into the future.

JEL Classification: $\quad$ J61

Keywords: $\quad$ EU expansion, migration, attitudes

Corresponding author:

David G. Blanchflower

Department of Economics

6106 Rockefeller Hall

Dartmouth College

Hanover, NH 03755-3514

USA

E-mail: david.blanchflower@dartmouth.edu 
The enlargement of the European Union from fifteen to twenty five countries since the Spring of 2004 has benefited the United Kingdom enormously. Since 2004 nearly nine hundred thousand workers from these countries have registered to work in the UK. In contrast to other member countries the UK Government allowed full access to its labour market to nationals of eight former Soviet-bloc countries (the Czech Republic; Estonia; Hungary; Latvia; Lithuania; Poland; Slovakia; and Slovenia - the A8 countries). ${ }^{1}$ However, the UK did restrict access to benefits. On the $1^{\text {st }}$ January 2007, Bulgaria and Romania (the A2 henceforth) joined the European Union: workers from these two countries were given much less open access to the UK labour market than those from the A8. ${ }^{2}$ Henceforth we refer to the group of ten East European countries as the A10.

Access to the UK to nationals from the A8 is allowed under the Worker Registration Scheme (WRS). Nationals of the A8 countries who wish to work as employees in the UK for a period of at least a month are required to register with the WRS. Workers who are self-employed do not need to register. Applicants must register more than once if they are employed by more than one employer. They must also re-register if they change employer. An individual who has registered to work and who leaves employment is not required to deregister, so some of those counted will have left the employment for which they registered and indeed some are likely to have left the UK. In contrast to the WRS both employed and self-employed workers from the A8 and A2 nations need to register for a National Insurance number (NINO) to work legally in the UK. ${ }^{3}$

A number of questions arise:

1) How many have come and how many have returned?

2) What are their characteristics?

3) Why did they come?

4) What has the impact of this influx of workers from these ten Eastern European countries been on the UK economy?

5) Will the flow continue in the future?

In what follows we examine these questions using data from a number of data sources. In the UK we make use of data from the WRS and NINOs as well as the Labour Force Survey. We also use data from a number of Eurobarometers 2004-2007 as well as the 2005 Work Orientation module International Social Survey Programme to look at the attitudes of residents of the A10 countries to examine factors likely to impact the propensity to move to the UK. Residents of the A10 countries report that they are

\footnotetext{
${ }^{1}$ Residents of Cyprus and Malta were also permitted to work in the UK from 2004, but the size of the flows are small and hence we concentrate on the more important flows from the Eastern European ten.

${ }^{2}$ For details of the work rules for nationals of Bulgaria and Romania see UK Border Agency (2008), Bulgarian and Romanian Accession Statistics, \#s1-5. http://www.bia.homeoffice.gov.uk/sitecontent/documents/aboutus/reports/bulgarianromanian/

3 The National Insurance Numbers reported here relate to the numbers allocated for employment purposes. A further 6,597 were allocated for benefit purposes and 13,998 for tax credit purposes.
} 
unhappy with their lives and the country they live in, are dissatisfied with their jobs and would find difficulties in finding a new job or keeping their existing job. Relatively high proportions express a desire to move abroad. Expectations for the future for the economy and their personal situations remain low but have improved since 2004. There has been some deterioration in the availability of jobs in the UK economy as the economy moves into recession, which a number of commentators have taken to imply the flow of workers from the A10 will slow. We examine the macroeconomic factors that are likely to impact the potential flow of workers in the future.

\section{1) How many have come and how many have returned?}

Table 1 provides the most recently available data from the Worker Registration Scheme As can be seen from column 1 of the table a cumulative total of 812,000 applicants have been approved on the WRS between 1 May 2004 and 31 March 2008. In addition there have been 10,540 worker registrations from Bulgaria and 22,080 from Romania. Overall, then there have been nearly 850,000 approvals from the A8 and A2. In addition, as is clear from columns 2 and 3 of the table, there have been a large number of re-registrations and multiple re-registrations. Re-registrations occur when those who have previously registered change employer. Multiple re-registrations are made by individuals working for more than one employer simultaneously. Re-registrations are widespread and are approximately half the number of total registrations suggesting there is considerable movement between employers, a point we return to below. Interestingly, despite the fact that there was a slowing in the number of new registrations between 2007q1 and 2008Q1 the number of re-registrations increased.

Data are also available on the number of individuals who have registered to obtain National Insurance numbers. Overall, between May 2004 and March 2008 there have been 841,200 National Insurance numbers allocated. In addition, there have been 37,968 registrations for National Insurance numbers for employment purposes from Bulgaria and Romania with approximately two thirds from Romanians between January 2007 and March 2008. ${ }^{4}$ In total then, approximately 880,000 individuals from the A10 have received a NINO for employment purposes since mid 2004.

Table 2 shows that two-thirds of those who have registered on the WRS have come from Poland (67\%), followed by Slovakia (10\%) and Lithuania (9\%). Less than one thousand have registered from Slovenia. The country mix of registrations in 2008Q1 was broadly similar to that in 2004.

It appears from the data in Tables 1 and 2 that there has been a slowing in the numbers of individuals registering on the WRS and also acquiring NINOs. Unfortunately this

\footnotetext{
${ }^{4}$ For example, in the latest data available between January and March 2008, the total number of National Insurance Number applications from Bulgarian and Romanian nationals stood at an overall total of 11,102. $98.0 \%$ of National Insurance $98.0 \%$ were allocated for employment purposes, $1.3 \%$ for benefit purposes and $0.6 \%$ for tax credit purposes. $66.3 \%$ of applications were from Romanian nationals and $33.7 \%$ from Bulgarian nationals. $63.5 \%$ of applications were from males and $36.5 \%$ were from females. $76.3 \%$ of applications were from people aged 18-34 years. Source: Bulgarian and Romanian Accession Statistics, January - March 2008, Home Office UK Border Agency.

http://www.bia.homeoffice.gov.uk/sitecontent/documents/aboutus/reports/bulgarianromanian/
} 
doesn't tell us about the number of workers in the UK at any one time as it is apparent that the vast majority of these workers are not migrants. The United Nations definition of a long-term international migrant is someone who moves to a country other than that of his or her usual residence for a period of at least a year so that the country of destination effectively becomes his or her new country of usual residence. It turns out that the number of migrants from the A8 is quite small. According to the recent ONS publication International Migration (2008) net migration from the A8 increased from 61,000 in 2005 to 71,000 in 2006. The estimate of the numbers of A8 citizens migrating into the UK for a period of at least a year increased from 53,000 in 2004 to 76,000 in 2005 and 92,000 in 2006. The increase between 2004 and 2005 can be explained by 2005 being the first full calendar year following the date of accession in May 2004 for which migration by A8 citizens could be estimated. These numbers are much lower than the numbers from the WRS and NINOs - the reason is that the vast majority of workers who have come to the UK from Eastern Europe are not migrants. They may subsequently change their mind and not return home in the future and become migrants but at the date of their entry to the UK that is not their apparent intention. They are temporary workers or commuters who have the legal right to work in the UK. The fact that these workers move in and out of the UK as jobs are available provides a degree of flexibility not seen with a group of migrants who arrive permanently into a country. The benefit to a receiving country of having temporary workers is that, if and when the economy slows they will return to their home countries, thereby slowing any potential rise in the unemployment. It is also possible that they can contain wage growth of the incumbent workforce who fear that they may be replaced.

Consistent with the number of migrants from the A8 being small, when asked how long they intend to stay in the UK, as part of their application to the WRS, in the twelve months ending March 2008 only 12\% said they intended to stay for a year or more while $60 \%$ said they intended to stay less than three months. So intended length of stay is short. Given the fact that the workers from Eastern Europe generally intend, and actually do, stay in the UK for relatively short spells, or as in the case of some from Bulgaria or Romania who are only allowed to stay for six months, in our view it is inappropriate to call them migrants; they should more appropriately be considered temporary workers.

There has been some previous work on return migration. LaLonde and Topel (1997), for example, found that 4.8 million of the 15.7 million US immigrants who arrived between 1907 and 1957 had departed by the latter year. Chiswick and Hatton (2003) pointed out that return migration exceeded immigration to the United States during the 1930s. Yang (2006) recently examined the economics of return migration for temporary labour migration by Filipinos. Yang found that, on average, a 10\% improvement in the exchange rate reduced the 12-month migrant return rate by 1.4 percentage points. This is a large effect, amounting to nearly one-fifth of the mean 12-month return rate in his sample. Constant and Zimmermann (2007) examine return or what they call 'circular' migration and argue that it is potentially a way to minimise psychological costs due to long separations from family members. Using evidence on the guestworker population in the German Socio-Economic Panel they found that more than $60 \%$ were repeat migrants. 
The probability of a migrant returning to the state of origin within a year is about 13 per cent and the probability of moving to another location is 15 per cent (Devanzo, 1983 and Dustmann, 2003). Zaiceva (2006) summarises the empirical literature on potential European migration flows, which she shows to be consistent with between 2 and 4 per cent of the residents of Central and East European countries (CEECS) moving west, in the long run, constituting around 1 per cent of the EU15 population. Zaiceva also presents evidence from simulations suggesting that the majority of migrants will be from Romania, Poland and Bulgaria, consistent with other estimates from the literature.

Christian Dustmann, in a number of papers, has undertaken the most complete analysis in the UK of the economics of return migration. Dustmann (1994), for example, suggests three potential motives for return migration 1) the migrant prefers consumption in the home country, 2) if prices are lower in the home country than in the host country this allows the entrant to take advantage of high wages abroad and low prices at home 3) human capital acquired in the host country is more valuable in the home country. Dustmann (1996) found that return propensities in Europe increase with age and decrease with the number of years of residence. Recently, Dustmann and Weiss (2007) have shown that return migration in the UK is not a new phenomenon. They explored this issue empirically before the influx from Eastern Europe using data from the LFS from 1992-2004. The authors found that, taking the population of immigrants who were still in the country one year after arrival as the base, about 40 per cent of all males and 55 per cent of all females had left Britain five years later. As we will show below it appears that the return rate for workers from the A10 is even more rapid than for those who have arrived in the UK from other countries.

2) What are their characteristics?

A good deal of data are available from the WRS and the LFS. The data source here is the WRS unless stated otherwise.

1) The vast majority who registered on the WRS are young - $43 \%$ are ages $18-24$ and $39 \%$ ages $25-34$ and $57.4 \%$ are men.

2) The workers who have come to Britain from the A10 are highly educated. While the LFS contains data on education it does not provide details of qualifications obtained outside the UK. However, it does provide information on the age when completed fulltime education. Based on weighted data from the LFS the average age for A10 workers was 20.1 overall and 20.3 for Poles compared with 17.6 for natives. A survey of more than 900 A8 workers in Fife found that nearly 30 per cent had a university degree, and a further 22 per cent had an under-graduate level qualification (Fife Research Coordination Group, 2008).

Interestingly, the finding that arrivals are dominantly young men is consistent with the findings in Blanchflower (2001) who examined attitudes of East European countries towards market reforms using data from East European Eurobarometers 1-8 for 19911997. The highest levels of support were found among the young, men and the most educated. Questions asked were i) whether they were satisfied with the way democracy was developing, ii) whether the 'free market was right for the country's future' and iii) 
whether 'things in the country are going in the right direction'. Support for all three in 1997 was especially high in Poland

3) Only 7\% of registered workers on the WRS had dependants.

4) The most important occupation is process operative (other factory worker) - 212,405 (27\%).and warehouse operative 63,690 (8\%).

5) $97 \%$ who applied in the twelve months to March 2008 were working $>16$ hours and $87 \%>35$ hours.

6) $53 \%$ worked for temporary employment agencies.

7) 70\% of workers who applied April 2007-March 2008 said their hourly wage was $£ 4.50$-£5.99 an hour while $23 \%$ stated their wage was £6.00-£7.99 an hour.

8) The highest proportion worked in East Anglia (14\%); the Midlands (13\%) and London (12\%).

9) London had the highest proportion of applications for National Insurance numbers (26\%) followed by the South East (13\%) and Scotland (10\%).

10) It is apparent that those from the A10 were much more likely to be in households with at least three adults than is the case for either natives or those from the non-A10 (47.7\%, 24.3\% and 27.6\% respectively), see Blanchflower and Shadforth (2009).

11) Only relatively small numbers have obtained work related benefits such as income support or Jobseekers Allowance. They came to work not to claim benefits. The main exception is that over 100,000 have received child benefits whereas only around 4,000 have received Jobseekers Allowance.

We now move on to examine the most recent data available from the LFS for the period December 2006-March 2008 on the extent to which A10 entrants to the UK differ from natives and migrants from elsewhere. To do this, we examine the probability that they work, the so-called employment to population ratio (EPOP); their wages and, conditional on working, whether they are self-employed; their usual hours; their earnings and whether or not they are a union member. We find that those from the A10 have high probabilities of working and being self-employed, and receive relatively low wages.

\section{a) Work}

We investigate the propensity to work of the new arrivals from the A10 in column 1 of Table 3 - this is the employment to population ratio (EPOP). Here the dependent variable is set to one if the respondent to the Labour Force Survey said they were working, either as an employee or self-employed, zero otherwise, including being unemployed or out of the labour force (OLF). The sample is restricted to those aged 16- 
70 and excludes students. ${ }^{5}$ The equation includes controls for age and its square plus controls for gender, race plus region of residence along with three year dummies. The equation also includes a variable identifying whether the individual's country of origin was in the A10 and whether they had arrived post 2003 or not and similarly for those from the non-A10. Both A10 variables are significantly positive with the new A10 having a nearly thirteen percentage point higher probability of working than natives compared with 5 percentage points for those who arrived pre-accession. In contrast the coefficients on both non-A10 variables are significantly negative suggesting those from the non-A10 have a significantly lower propensity to work than either the indigenous population or those who were born outside the A10 no matter when they arrived. Interestingly, in contrast to the new A10 arrivals the new non-A10 arrivals have a significantly lower probability of working than those who arrived before 2004 .

\section{b) Self-employment}

In almost all countries for which data are available, OECD (2006) found that selfemployment among immigrants has increased over the past few years, both in numbers and as a percentage of overall self-employment. In some countries, the OECD found that the increase has been particularly apparent. Foreign-born persons accounted in 2004 for some 11\% of total self-employment in France and the United Kingdom, 12\% in Belgium and nearly 14\% in Sweden, figures which are generally higher than the share of immigrants in the total labour force. Dustmann and Kirchkamp, (2002) found in their study of Turkish immigrants to Germany who returned home subsequently, that approximately half became active as an entrepreneur on their return. Blanchflower and Shadforth (2009) reported, based on the Flash Eurobarometers - 'Entrepreneurship', 2000-2004 that a high proportion of workers in Lithuania (62\%) and Poland (57\%) reported that they would like to be self-employed. ${ }^{6}$ In both of these countries Blanchflower and Shadforth also found that relatively high proportions of workers reported that it was hard to start a business due to a lack of financial support (52\% and $42 \%$ respectively compared with $24 \%$ in the UK and $26 \%$ in the USA). In part the desire to come to the UK may well be to raise capital to help overcome liquidity constraints at home.

It is appropriate then to examine the incidence of (self-reported) self-employment among A10 workers given that the self-employed do not have to register under the WRS, although they do have to apply for a NINO. Column 2 of Table 3 reports the results estimate the probability of a worker being self-employed using a dprobit, with the

\footnotetext{
${ }^{5}$ We exclude students on the sensible suggestion of Jonathan Wadsworth who in private communication suggested that in his work with John Schmitt they find that the results are sensitive to their inclusion.

${ }^{6}$ The question asked was "suppose you could choose between different kinds of jobs. Which one would you prefer - being an employee or being self-employed'. The \% preferring self-employment was as follows for the other A8 countries - Czech Republic 37\%; Estonia 49\%; Hungary 47\%; Latvia 44\%; Slovakia 36\% and Slovenia 35\% compared with 43\% in France; 46\% in Germany; 47\% in the UK and $66 \%$ in the USA. For more on the desire to be self-employed across countries see Blanchflower, Oswald and Stutzer (2001).
} 
dependent variable set to one if self-employed and zero if a worker. ${ }^{7}$ The results are standard, in that the probability of being self-employed higher for men, Asians and Chinese, rises with age and is especially high for those with a trade. ${ }^{8}$ It is low for blacks and the young and for those with an HND, teaching or nursing ('other') qualification only. Foreign workers who arrived before 2004 have a higher probability of being selfemployed than natives; those from the A10 have a particularly high probability, but more recent arrivals have lower probabilities. It is apparent that recent arrivals from the A10 have a particularly low propensity to be self-employed. Of course, this may be because in part because of the difficulty of capturing the self-employed from the A10 in the LFS.

\section{c) Usual hours and work limiting problems.}

Usual hours worked is estimated in column 3. Workers whose origin was from the A10 work longer hours: those A10 workers who arrived post 2003 work on average 3.9 hours longer than natives. In the LFS workers report whether they have a condition that limits their ability to work. The probability a worker reports such a condition is estimated in column 4. Recent arrivals from the A10 are much less likely than natives to report such a condition.

\section{d) Wages and union membership.}

There is also evidence to suggest that these Eastern European workers in general and recent arrivals in particular, are being paid relatively low wages, ceteris paribus. Data are available on this in the Labour Force Surveys. Column 5 of Table 3 reports the results of estimating a log hourly wage equations using data from the 2004-2007 LFS. Sample sizes are smaller than in column 2-4 as the sample is restricted to employees only and restricted further because wages are only asked in wave 1 and wave 5 of the survey. $^{9}$ In total then there are approximately eighty-three thousand observations. It is apparent that recent arrivals from the A10 have particularly low wages, ceteris paribus. For example, in column 5, recent A10 workers receive 12.5\% lower wages than natives obtained by taking anti-logarithms and deducting one. Interestingly non-A10 migrants have significantly higher wages $(+6.6 \%)$ than natives, holding constant their characteristics, including race (column 6). ${ }^{10}$ The OECD (2006, p.222) reports that one of the main features of labour immigration into the United Kingdom prior to the influx of workers from the A10 was the high proportion accounted for by corporate transfers. The OECD noted that in 2005 a quarter of the interviewees working abroad a year before and in the United Kingdom at the time of the interview were working for the same

\footnotetext{
${ }^{7}$ The dprobit command in STATA reports the marginal effect, that is the change in the probability for an infinitesimal change in each independent, continuous variable and, by default, reports the discrete change in the probability for dummy variables.

${ }^{8}$ See Blanchflower (2004) and Blanchflower and Shadforth (2009).

${ }^{9}$ In the LFS since 1997 a fifth of the sample each quarter is replaced and individuals stay in the sample for 5 consecutive waves or quarters.

${ }^{10}$ Drinkwater et al (2006) found from an analysis of wages in the Labour Force Surveys of 2001-2006, that Poles had lower rates of return to their human capital than other recent migrants, even after controlling for other personal and job-related characteristics.
} 
employer. This may, in part, help to explain the higher earnings of the non-A10 workers.

Column 6 suggests that in part these lower wages arise because foreign-born workers are much less likely to be union members than natives. It is will know that there are significant wage benefits from being a member of a union (Blanchflower and Bryson, 2003, 2008)

In summary, the new arrivals from Eastern Europe who have come to work in the UK tend to be young, male, healthy, educated, non-union and unmarried. Approximately one third work for recruitment agencies. They disproportionately work in East Anglia and the West and East Midlands. Holding constant a variety of characteristics including age, qualifications and location, A10 workers who arrived since Accession in 2004 have higher self-employment rates, longer working weeks, are fitter, have lower wages, are less likely to be union members and have higher employment to population ratios than natives. In contrast, recent non-A10 migrants are less likely to work but when they do they obtain higher wages than natives.

\section{3) Why did they come?}

In this section we examine the reasons for the influx of workers from the Accession Countries since 2004. We make use of data from a number of Eurobarometers obtained since 2004, with the most recent taken at the end of 2007. It appears that, consistently, on a large number of measures and from several different data files respondents from former Communist countries are unhappy with their lives, their jobs, the country they live in and the economic situation of their country as well as prospects for the future (Blanchflower and Freeman, 1997 and Blanchflower, 2001, 2008). The answers are broadly consistent across data sets and vary little across different questions. Significantly high proportions of the residents of these countries report they have thought about living abroad. Relatively high proportions of workers in the A10 say they would be prepared to move abroad if they became unemployed. Unemployment appears to be a particular concern in these countries. Specifically we provide evidence in this section that in comparison with other EU countries, respondents in these A10 countries, report that in their own country the following is true.

a) It is difficult to find a good new job.

b) Levels of job satisfaction are low.

c) Workers feel insecure about their jobs and fear that it is easy to replace them

d) Work/life balance is poor.

e) Low happiness and life satisfaction levels with their lives as well as with their reported happiness with the country in which they live.

f) Expectations of the macro-economy are low.

g) They are particularly worried about inflation and unemployment.

h) They would move abroad if they were made unemployed

Each of these factors shows low levels of satisfaction and contentment in the A10 which are likely to provide an incentive to leave. It appears that leaning English has been an attraction to many. 


\section{a) Job satisfaction}

Table 4 examines how hard it is to find a good job, job satisfaction and work/life balance using data from Eurobarometer \#64.1 for 2005 covering the EU-25 and including the A8. Columns 1 and 2 - for workers only - report ordered logits where the dependent variable is how difficult it would be to find a good job, scored as $4=$ 'totally agree'; $3=$ 'tend to agree'; $2=$ 'tend to disagree' and 1='totally disagree'. First, it appears that it is especially difficult to find a good job in the A8 countries: the coefficients on each of the country dummies for the A8 countries are large and especially so in Hungary.

Columns 3-6 are for workers only: columns 3-5 estimate job satisfaction ordered logits in relation to salary, number of hours and the balance between your private life and their working life. Column 6 estimates an OLS where the dependent variable is the sum of ten job satisfaction variables, each coded 1-4 (mean=30.9: $s d=4.7)$. Job satisfaction on each of the four measures is U-shaped in age (Clark, Oswald and Warr, 1996). Workers in these East European countries in general, and in Hungary in particular, were dissatisfied with their jobs. This is consistent with findings by Blanchflower and Freeman (1997) who also found, using data from the 1989 ISSP survey that job satisfaction levels were lower in Hungary than in Western countries. Work-life balance in column 5 was lowest in these countries, particularly in Latvia and was lower for the most educated.

Table 5 provides evidence on worker's views on their working conditions using data from the 2005 International Social Survey Programme (ISSP) for thirty two countries, including five from the A10 (Bulgaria, Czech Republic; Hungary Latvia and Slovenia) plus Russia as well as eight non-EU developed (Australia, Canada, Israel, Japan, New Zealand, Norway, Switzerland and the USA) and six less developed countries (Dominican Republic, Mexico, Philippines, Taiwan, South Africa and South Korea). Workers are asked to report on their job satisfaction, their job security and how easily their employer could replace them. Workers in the five A10 countries are especially likely to report low levels of job satisfaction and job security, confirming the findings in Table 4 above using the Eurobarometers. Workers in Bulgaria, Czech Republic, Hungary were especially likely also to report that it would be easy for their employers to replace them.

\section{b) Life satisfaction}

It is well known that residents in the A10 are particularly unhappy with their lots (Blanchflower and Freeman, 1997; Blanchflower, 2001 and Blanchflower and Shadforth, 2009). There has been some improvement over time in life satisfaction levels. Table 6 presents the mean scores from Eurobarometers \#62.0 for 2004 and \#68.1 for 2007 where $1=$ not at all satisfied; $2=$ not very satisfied; $3=$ fairly satisfied and $4=$ very satisfied. Eurobarometer \#62.0 is the first in the series to include individuals from the new Accession Countries. Levels of happiness increased in all countries except Hungary and Slovenia between 2004 and 2007 but, except for Slovenia, the scores remain well below the UK score, especially in Bulgaria. Data are also available in these two data files on their expectations, 12 months ahead, for themselves and for the economy. The proportion who say that they expect the next 12 months to be 'better', with the other alternatives being 'the same' or 'worse'. In general there has been some improvement especially in Poland, Lithuania, Latvia and Slovakia - but a worsening on all dimensions 
in Hungary since 2004. It is notable that workers in Bulgaria, the Czech Republic and Hungary, as well as in the UK, are less optimistic over time about their personal job prospects.

Table 7 also makes use of data from Eurobarometer \#68.1; it also includes data for Turkey; Croatia and Macedonia who are in the process of applying for EU membership. Column 1 reports the econometric results of estimating a life satisfaction ordered logit with standard controls. Happiness is high in Denmark, the Netherlands and Sweden. It is apparent from column 1 of Table 7 that life satisfaction is especially low in Bulgaria, Romania and Hungary. ${ }^{11}$ Indeed, in comparison with the levels of prevailing in the UK, ceteris paribus, life satisfaction is significantly lower in all of the A10 countries. As has been found in earlier work, happiness is U-shaped in age, rises with level of education, is higher for married people, women and for the self-employed (Blanchflower and Oswald, 2004, 2008; Blanchflower, 2008). Following Di Tella and MacCulloch (2005), rightwing voters are happier than left wing voters. The unemployed are especially unhappy. ${ }^{12}$ The results are very similar in column 2 when an equation is estimated for the A10 countries alone. As for the EU29 as a whole, happiness rises with schooling, is higher for the married, right-wing voters and the self-employed, U-shaped in age and lower for the unemployed. Once again Bulgarians, Romanians and Hungarians are the least happy and Slovenians the most happy. One reason workers came is likely to have been because they were unhappy at home. It remains unclear if the least happy left which then raised the happiness levels.

\section{c) Macro-economy}

Columns 3 and 4 of Table 7 provide evidence on respondents' views on the 'two most important issues facing their country'. Two answers are possible and the survey data identifies simply the two (out of a list of fourteen, including crime, taxation, terrorism, health care, pensions and education) that were mentioned. Here we model the probability of mentioning unemployment (column 2); rising prices/inflation (column 3). ${ }^{13}$ Worries about inflation are high in Estonia, Latvia and Lithuania and about unemployment in Poland, Macedonia, the Slovak Republic and East Germany.

In column 5 an ordered logit is estimated which models whether respondents believe the economy is headed in the right direction (1=wrong direction: 2=neither; 3=right direction). The responses from this question convey a rather different message to the rest of the table: residents of the A10 are more likely to believe their country is moving in the right direction than is the case in the UK which is the excluded category. Half are

\footnotetext{
11 The question used in the Eurobarometers is 'On the whole, are you very satisfied=4, fairly satisfied=3, not very satisfied $=2$, or not at all satisfied $=1$ with the life you lead?'.

12 The results are very similar when an equation is estimated for the A10 countries alone (results not reported). Happiness rises with schooling, is higher for the married, right-wing voters and the selfemployed, U-shaped in age and lower for the unemployed. Once again Bulgarians, Romanians and Hungarians are the least happy and Slovenians the most happy.

${ }^{13}$ The weighted mean responses were highest for these two categories - unemployment (30.7\%) and rising prices (23.8\%).
} 
significantly more optimistic than UK respondents (Estonia, Lithuania, Romania, Slovakia and Slovenia); three are the same as the UK (Bulgaria; Czech Republic and Poland) while Hungarians and Latvians are significantly more pessimistic.

\section{d) Propensity to move abroad}

Table 8 uses data from two further Eurobarometer (\#65.1 for 2006 and \#64.1 for 2005) to explore further the issue of the potential flow of workers from the A8 Accession Countries. Columns 1-3 use Eurobarometer \#65.2 while columns 4 and 5 use Eurobarometer \#64.2. Column 1 presents the results from estimating an ordered logit, with the dependent variable whether the individual reports whether they are happy to live in that country. Results are very similar to those in Table 6 for individual happiness - happiness living in that country is highest in Denmark and lowest once again in Hungary and the Czech Republic. Men are less happy: those who live in rural areas are especially happy with the country they live in. More young children raise happiness. Column 2 reports the results of estimating the probability that an individual reports they either had worked abroad or were 'thinking of it but hadn't decided yet' for the East European countries, including East Germany, only. Column 3, also only for the East Europeans reports the probability the individual had only worked abroad. In both cases the Czechs were least likely to have worked abroad or thought of doing so. As might be expected, men were especially likely to have worked abroad as were the more highly educated and managers as well as those living in urban areas. Columns 4 and 5 provide supporting evidence for the nine East European countries. Column 4 reports the result of estimating dprobits that model the probability that an individual says they will move to another EU country in the next five years (column 4) and is particularly high in Lithuania and Latvia. ${ }^{14}$ Columns 5 and 6 estimate dprobits where the dependent variable is whether the worker would be prepared to another country if they become unemployed. Column 5 is for the East European countries only while column 6 is for the EU25. The proportion who say they would move abroad if unemployed was especially high in Lithuania (20\%) and Latvia (19\%), Poland (12\%), Estonia (10\%) and Hungary (8\%) and lowest in Finland (2\%). The probabilities in columns 5 and 6 of Table 8 are also highest in Lithuania and Latvia, which have seen the highest proportion of their population moving to the UK. The probability declines with age, is higher for men.

These findings are consistent with those reported by Blanchflower and Shadforth (2009) who used data from the Candidate Eurobarometer 2002.1 (ZA\#4153) conducted in March-April 2002 to examine Eastern European's intentions to live and work in the EU in the following 5 years (conducted in 2001). They found that the probability of being willing to move was higher among the young; men; the unmarried and divorced; the most educated; professionals and business proprietors; and especially residents of Latvia, Poland and Slovakia. Unsurprisingly, workers from the A10 seem to have come to the UK to improve their lives. A significantly high proportion say that they would be prepared to move abroad in the future.

\footnotetext{
${ }^{14}$ A further option offered to respondents is that they would move to another country or region. We only model the proportion who say they would move to another EU country.
} 
The evidence suggest that East Europeans are unhappy with their lives and with the country generally. Workers are dissatisfied with their salaries; the number of hours they work and their work/life balance. They are concerned about the availability of good jobs and are insecure about their jobs. All these reasons present a reason to move abroad. This is consistent with the literature that focuses on the economic factors that determine migration. Very simply, the literature says that individuals will compare the income benefits from migration with the economic and social costs of moving. If the benefits outweigh the costs, they may choose to migrate. The gain from moving will be calculated as the expected income differential between the destination country and the country of origin, which will in turn be determined by the relative probability of getting a job - captured by differences in the unemployment or employment rates.

Pollard et al (2008) interviewed 370 Poles who had returned home after working in the UK. They found that wanting to learn English was a significant attraction for many. They also found for many young people it was a way of 'broadening horizons'. Pollard et al (2008) also found that Poles registered on part-time courses as a way of learning new skills which were often not available at home.

"..the strength of the UK economy has also acted as a 'pull' factor for many migrants. High levels of spending, low unemployment, and high demand for labour especially in sectors such as construction have acted as draws for many post enlargement migrants. The strength of the British currency in recent years has acted as a particular pull, allowing earnings and savings from the UK to go even further when spent in migrants' home countries." Pollard et al (2008), p.43.

Working in the UK is thus an opportunity for many to save money. The survey by the Center for International Relations in Warsaw of high-skilled Poles working in Britain found that 65 per cent were saving some of the money they were earning, and that 60 per cent of this group were sending money home to Poland (Iglicka, 2008).

\section{4) What has been the impact on the UK labour market?}

The empirical literature from around the world suggests little or no evidence that immigrants have had a major impact on native labour market outcomes such as wages and unemployment. Recent work by a number of other authors for the UK is also consistent with this view. For example, there is little evidence that immigrants have had much impact on wages (see Manacorda et al 2006, and Dustman et al, 2005) Such evidence there is suggests that if there is any impact it is on the wages of the least skilled. Blanchflower and Shadforth (2009) found a small negative relationship between the change in the annual rate of wage inflation of those in elementary occupations (defined in the LFS as SOC 9) between 2005 and 2006 and the change in the share of A8 workers one year earlier, as recorded in the WRS in 2004 and 2005, across regions. A similar result was reported by Nickell and Saleheen (2008) who found a small negative relationship, primarily in the semi-skilled unskilled services sector.

There is no credible statistical evidence that the arrivals from the A10 had any perceptible impact on unemployment. Gilpin et al (2006) found 'no discernible statistical evidence to suggest that A8 migration has been a contributor to the rise in 
claimant count unemployment in the UK' (p.1, 2006). That work was recently updated by Lemos and Portes (2008) who found a similar result overall as well as for sub-groups.

Increasing numbers of A10 workers in the UK, however, may well have increased the 'fear' of unemployment which tends to have a downward impact on pay especially in the non-union sector (Blanchflower, 1991). Blanchflower and Shadforth (2009) modelled the responses to the above question and found that the fear of unemployment is higher the longer job tenure is, and is lower for the more educated, for those on indefinite contracts, full-timers and those who work in the public sector. The fear of unemployment was found to be highest in the East European countries and lowest in Norway and France. The authors also modeled the impact the fear of unemployment has on earnings, defined as the respondent's net monthly income from their main paid job and found that the fear of unemployment lowers wages. This confirms the findings in Blanchflower (1991), which showed that the probability of job loss appears to have a powerful effect upon earnings. Workers who stated that they expected to be made redundant did not receive a compensating differential but were paid, on average, approximately $8 \%$ less, ceteris paribus. One possibility is that bad workers have a relatively high fear of redundancy because of their poor performance. However, Blanchflower (1991) argued that fear of unemployment itself, and not poor worker quality, is the explanation for the significant coefficient on the redundancy dummy. One possible way around this problem is to exploit the fact that when plants close both good and bad workers lose their jobs. Thus, as a check the 'redundancy expected' variable for the UK was replaced with one relating to the expectation of plant closure which also lowered pay by $8 \%$. This seems to support the idea that fear of unemployment is not primarily a proxy for worker quality.

A recent, monthly survey of consumers conducted by the European Union is also consistent with the view that the fear of unemployment in the UK has risen and been above its long run average since around 2005. ${ }^{15}$ The Directorate General for Economic and Financial Affairs of the European Commission conducts regular harmonised surveys for different sectors of European Union and applicant country economies. They are addressed to representatives of the industry (manufacturing), the services, retail trade and construction sectors, as well as to consumers. Consumers in each monthly survey are asked (Q7): "How do you expect the number of people unemployed in this country to change over the next twelve months? The number will a) increase sharply b) increase slightly c) remain the same d) fall slightly e) fall sharply f) don’t know.” The answers obtained from the survey are aggregated into a survey 'balance'. Balances are constructed as the difference between the proportion giving positive and negative replies. The Commission calculates EU and euro-area averages on the basis of the national results and seasonally adjusts the balance series.

Chart 1 plots three-month averages of the survey balances (advanced 12 months) against the actual unemployment rate for the UK; the EU-15, Ireland and Sweden. The fear of unemployment and actual unemployment has risen since around 2004 in both the UK and Ireland, both of whom had large influxes of workers from the Accession countries.

${ }^{15}$ See http://ec.europa.eu/economy_finance/db_indicators/surveys9185_en.htm 
The fear of unemployment declined in the EU-15 between 2004 and mid 2007. ${ }^{16}$ Interestingly, the survey balances over this time period fell in Austria; Belgium; Denmark; Finland; France; Germany; Luxembourg; the Netherlands; Portugal and Sweden while those for Greece, Italy and Spain were essentially flat. Since mid 2007 the survey balance has ticked up in the EU-15 as a whole and in every country except Luxembourg despite the fact that unemployment has continued to fall in all countries except Spain and Portugal.

Among the A10 accession countries survey balances have declined over this period in all of the countries except Hungary, which saw an increase. Over the last year or so unemployment expectations have picked up quite sharply in Latvia and to a lesser extent in Lithuania. The fear of unemployment is especially high in Hungary.

Of particular interest are the survey balances and unemployment rate for Ireland, which is the only other major country in the EU that has experienced a big increase in migration from the A10. Ireland's population increased by 313,000, or 8.1\%, between 2002 and 2006. Of this increase 213,000 was from migration. The largest increases were from Poland $(+60 \mathrm{k})$; Lithuania $(+22 \mathrm{k})$ and $+40 \mathrm{k}$ from the rest of the EU-25 excluding Britain and Northern Ireland. ${ }^{17}$ According to the 2006 Census (Table 29A) 129,000 people whose birthplace was in Eastern Europe were living in the Irish Republic. ${ }^{18}$ These numbers are dramatically higher than they were in the 2002 Irish Census, when there were only approximately 2,000 Poles and Lithuanians living in Ireland.

Interestingly, the fear of unemployment in Ireland rose, as it did in the UK as the number of East Europeans in the country increased since 2002, even though there has been no change in unemployment in Ireland. ILO unemployment has remained steady in Ireland at $4.4 \%$ between 2002 and 2006. ${ }^{19}$ Consistent with a rise in the fear of unemployment, average earnings growth has fallen since 2003 from $6.4 \%$ to $3.1 \%$ (Blanchflower and Shadforth, 2009). In 2007 unemployment rose to an average of $4.6 \%$ and to $5.4 \%$ in

\footnotetext{
${ }^{16}$ We calculated the series for EU-15 weighted according to the population of each country for each year. Due to the availability of the data, the EU-15 series for unemployment expectations includes:

Jan85-Mar86 -- UK, Belgium, Denmark, Germany, Ireland, Greece, France, Italy, Netherlands

Apr86-Aug87 -- as above, plus Portugal and Spain

Sep87-July95 -- as above, plus Finland

Aug95-Oct01 -- as above, plus Sweden and Austria

Nov01 -- as above, plus Luxembourg

And the EU-15 series for unemployment rate includes:

Jan85-Dec94 -- UK, Spain, France, Italy, Netherlands, Austria, Portugal, Finland, Sweden

Jan95-Dec96 -- as above, plus Belgium, Denmark, Germany, Ireland

Jan97-Mar98 -- as above, plus Luxembourg

apr98-Dec06 -- as above, plus Greece

${ }^{17}$ http://www.cso.ie/census/documents/PDR\%202006\%20Commentary.pdf

${ }^{18}$ http://www.cso.ie/census/documents/Final\%20Principal\%20Demographic\%20Results\%202006.pdf

${ }^{19}$ http://www.cso.ie/statistics/sasunemprates.htm
} 
May 2008. The fear of unemployment has risen especially sharply in 2008 - from 39.7 in October 2007 to 55.0 in May 2008, as unemployment started to rise.

Wage pressure in the UK has been contained despite the fact that there have been historically low levels of unemployment. This certainly appears to be consistent with the wage data that is available from a number of sources reported in Chart 2 which provides evidence from the Labour Force Survey. This is a random sample of workers and it suggests that wage pressure has remained muted in the UK.

The evidence suggests that the flow of workers from the A10 has had little or no impact on unemployment. It appears to have had some direct effect on the relative wages of the least skilled. Their main impact has been to raise the fear of unemployment, which has had the effect of containing wage growth.

5) Will the amount of work done by workers from the A10 decline in the future?

We don't know. There are grounds for believing that it will but there are also arguments to the contrary. As is apparent from Table 1, there has been some slowing in the number of new registrations on the WRS in 2008Q1. The UK economy has started to slow, house prices are falling, unemployment has started to rise as have commodity and oil prices and the pound has fallen against the Euro and the Zloty and the other currencies in the A10. This makes the UK a less attractive place to work, as the relative rates of return have fallen. However, the rise in oil and commodities is an international phenomenon; other economies are starting to slow and labour markets are loosening. Other EU countries are reducing their restrictions on workers from Eastern Europe, so they would have more destinations to choose in future. However, other economies are weakening too, so the relative attractiveness of the United Kingdom would not necessarily diminish significantly.

A recent special survey conducted by the Bank of England's Agents in the Spring of 2008 found that firms had no expectation of diminishing their use of migrant labour in the future. However, as the labour market loosened the Agents reported that more UK residents are applying for low-end jobs. There was some evidence that Polish workers were less prepared to do unskilled work at the National Minimum Wage, while more recent Polish arrivals were less likely to speak English and tended to be older and less qualified than the earlier tranches. Although there was no obvious lack of supply there some evidence was found that employment agencies were switching to workers from countries other than Poland.

The development of network effects, however, has made it easier for workers to obtain work in the UK. In addition the fact that English is an international language continues to make the UK attractive. There is also the possibility that the mix of workers may change. Relatively small numbers of workers have come to the UK from the Czech Republic and Hungary and this may change in the future. Indeed, there is evidence that the Hungarian economy is slowing fairly rapidly which is likely to provide larger incentives to come to the UK. Moreover, even if the relative attractiveness of the UK wages are a good deal higher than they are back home. 
Pedersen et al (2004) found that network effects measured as the coefficient of the stock of immigrants of own national background already resident in a country has a large positive effect on immigration flows, and concluded that networks play an important role in explaining current immigration flows. Further, linguistic closeness, former colonial and current business ties the authors found had a significant impact on migration flows. Geographic distance, on the other hand, had a negative impact on migration flows suggesting that the costs of migration play an important role.

Pollard et al (2008) note a number of factors that have made it easier for Poles to move back and forth to the UK. By December 2007, it was possible to fly from 22 British airports to ten Polish cities, and passenger numbers between these destinations that month were almost 385,000. In total some 10 million air passengers traveled between the UK and A10 countries in 2007, a three-fold increase on pre-enlargement air traffic.

Another indicator Pollard et al (2008) note is the growth in sales of A8 - primarily Polish - goods and services in the UK. For example, there have been several hundred Polish delis established throughout the country over the last four years. Established suppliers have been catering to the increased demand for Polish goods. In July 2007, Tesco announced that it was doubling both its range of Polish products and the number of stores stocking them. Tesco now sells Polish food in more stores in the UK than Poland, where it has 280 shops. Similarly, the leading Polish beer brands Lech and Tyskie were not widely available in the UK prior to 2004. According to the brands' owner SABMiller, annual UK sales of the two beers now exceed 44 million pints per year.

Pollard et al (2008) interviews of Poles in London suggests that those who settle in the UK long term often move into jobs that are more suited to their skills, especially once their English skills have improved. They authors also provide evidence that enterprising young people from the new accession countries are attracted to the UK to set up new businesses. They note that the British-Polish Chamber of Commerce estimates on its website (http://bpcc.org.pl/en/content/view/192/) that there are currently 40,000 Polish entrepreneurs who have set up businesses in the UK. ${ }^{20}$

Sachdev and Harries (2006) interviewed a number of workers from the A8 and found that the three main reasons for coming to the UK were a) to learn English b) to earn money c) to 'gain a new experience'. They found that most respondents were uncertain about how long they wanted to stay in England. Workers were more likely to stay if they had settled down by forming relationships and having families and/or had invested in their career. If individuals had undertaken training courses or had reached a certain position in their chosen profession they were more likely to remain in this country for a longer term. They were more likely to leave if they had been unable to adjust to life in England or if they were planning to finish full-time education or wished to seek a job in a multi-national company based on their existing qualifications where they could use their competency in English.

\footnotetext{
${ }^{20}$ The first sentence on the website says - 'UK-Polish trade is booming; there are 400,000 Poles living in London and the South East, and 40,000 Polish entrepreneurs have set up businesses in the UK'.
} 
The impact of the net flows into and out of the UK are harder to calculate as this will also depend on the flows of UK residents out of the UK. To the extent that other countries such as Australia, Ireland and Spain start to slow, these will lower the attractiveness of migrating their from the UK. It may well also induce further return migration as economic conditions and the housing market deteriorate abroad.

\section{6) Conclusions}

In summary, the favourable macroeconomic climate (low unemployment) and high standard of living in the UK (GDP per capita) are reasons why immigrants from the A10 countries may have been attracted to the UK between 2004 and 2007. Rapid GDP growth in some A10 countries, appreciation in their exchange rates and improvements in their unemployment rates might suggest a reduction in the flows of both permanent migrants and especially temporary workers to the UK from the A8 countries in the future. However, during 2008 there has been some slowing not just of the UK but in a number of the A10 economies, although it should be said that the Polish economy has looked the most resilient. This might impact on the mix of workers who come to the UK, with fewer from Poland and more from countries such as Hungary and Slovakia. Anticipated and legally required changes in the immigration policies of other EU member states that will allow greater access to migrants from the A10 may also lead flows to the UK to fall as other opportunities become available. However, the establishment of network effects, which has occurred in the UK, particularly for Poles, tend to have a large positive impact on immigration flows.

The fact that the UK opened its borders to a flow of highly skilled, motivated, educated, low cost mobile workers upon EU-enlargement was a stroke of genius, for which the UK government should be given credit. Indeed, the arrivals who have come to the UK post EU enlargement have higher probabilities of working than recent non-A10 or earlier migrants. Contrary to the fears of some, these recent post enlargement arrivals from Eastern Europe appear to have had no difficulty in assimilating into the native population who have welcomed them with open arms. By the time countries such as Germany and Austria moved to consider opening their borders it was too late. Networks had developed and large numbers of Poles, Slovakians, Lithuanians and Latvians were living and working in the UK.

We have found a great deal of evidence from a large number of data sources suggesting that residents of these A10 countries express deep dissatisfaction with their lives in these countries. They report difficulties in finding good new job; job satisfaction and happiness levels are low, job insecurity is high and work/life balance is poor. They report being concerned about the macro-economy. The economic situation in these countries is also deteriorating as the world economy slows. Respondents in the A10 continue to report that they would move abroad if they were made unemployed. In any case once economic conditions in the UK improve there is every likelihood that they will return in even larger numbers that before, helped by highly developed networks. The UK is an attractive place to live and work for the residents of the former Soviet bloc countries. This suggests that rather than dissipate, flows to the UK could remain strong well into the future. It is feasible, though, that the mix of source country may change over time. The enlargement of the European Union from fifteen to twenty five countries has benefited the United Kingdom enormously. 


\section{References}

Blanchflower, D.G. (1991), 'Fear, unemployment and pay flexibility', Economic Journal, March, pp. 483-496.

Blanchflower, D.G. (2001). 'Unemployment, well-being and wage curves in Eastern and Central Europe', Journal of Japanese and International Economies, vol. 15(4), pp. 364402.

Blanchflower, D.G. (2004), 'Self-employment: more may not be better', Swedish Economic Policy Review, vol. 11(2), pp. 15-74.

Blanchflower, D.G. (2008), 'International evidence on well-being', in National Time Accounting and Subjective Well-being, edited by Alan Krueger, NBER and University of Chicago Press, forthcoming.

Blanchflower, D.G. and A. Bryson (2003), 'Changes over time in union relative wage effects in the UK and the US revisited', in International Handbook of Trade Unions, Edited by John T. Addison and Claus Schnabel, Edward Elgar, Cheltenham/England and Northampton/ Mass..

Blanchflower, D.G. and A. Bryson (2008), 'The wage impact of trade unions in the UK public and private sectors', Economica, forthcoming.

Blanchflower, D.G. and R.B. Freeman (1997), 'The attitudinal legacy of Communist labour relations', Industrial and Labour Relations Review, 50(3), pp. 483-459.

Blanchflower, D.G. and A.J. Oswald (2004), 'Well-being over time in Britain and the United States', Journal of Public Economics, 88(7-8), July, pp. 1359-1386.

Blanchflower, D.G. and A.J. Oswald (2008), 'Is Well-being U-shaped over the life cycle?', Social Science and Medicine, 66, pp. 1733-1749

Blanchflower, D.G., and C. Shadforth (2009), 'Fear, unemployment and migration', Economic Journal, forthcoming.

Clark, A.E., A.J. Oswald and P. Warr (1996), 'Is job satisfaction U-shaped in age?", Journal of Occupational and Organizational Psychology, 69, pp. 57-81.

Constant A. and K.F. Zimmermann (2007), 'Circular migration: counts of exits and years away from the host country', Institute for the Study of Labor, IZA, Discussion Paper \#2999, August.

Devanzo, J. (1983), 'Repeat migration in the United States: who moves back and who moves on?', Review of Economics and Statistics, 65, November, pp. 552-559.

Di Tella, R. and R. MacCulloch (2005), 'Partisan social happiness', Review of Economic Studies, 72(2), pp. 367-393, April. 
Drinkwater, S., J. Eade and M. Garapich (2006), 'Poles apart? EU enlargement and the labour market outcomes of immigrants in the UK', IZA Discussion Paper \#241, October.

Dustmann, C. (1994), 'Return intentions of migrants, theory and evidence', CEPR DP \#906.

Dustmann, C. (1996), 'Return migration: the European experience', Economic Policy, 22, pp. 215-250.

Dustmann, C. (2003), 'Return migration, wage differentials and the optimal migration duration', European Economic Review, April, pp. 353-367.

Dustmann, C., F. Fabbri and I. Preston (2005), 'The impact of immigration on the British Labour Market', Economic Journal, vol. 115 No. 507, pp. 324-341.

Dustmann, C. and O. Kirchkamp (2002), 'The optimal migration duration and activity choice after re-migration', Journal of Development Economics, Vol. 67, pp. 351-372.

Dustmann, C. and Weiss, Y. (2007). 'Return migration: theory and empirical evidence from the UK', British Journal of Industrial Relations, vol. 45(2), pp. 236-256.

Fife Research Coordination Group (2008) 'Migrant Workers in Fife Survey 2007', www.fifedirect.org.uk/uploadfiles/publications/c64MigrantWorkersSurveyKnowFifeFind ingsV1 2.pdf

Gilpin, N., M. Henty, S. Lemos, J. Portes and C. Bullen (2006), 'The impact of free movement of workers from Central and Eastern Europe on the UK labour market' Department of Work and Pensions, Working paper \#29.

Home Office (2008), Accession Monitoring Report May 2004 - March 2008.

LaLonde, R., and Topel, R. (1997), 'The economic impact of international migration and the economic performance of migrants,' in Rosenzweig, M.R. and Stark, O. (Eds.), Handbook of Population and Family Economics, Amsterdam: Elsevier Science.

Lemos, S. and J. Portes (2008), 'The impact of migration from the new European Union Member States on native workers', working paper, Department for Work and Pensions.

Manacorda, M., A. Manning and J. Wadsworth, (2007), 'The impact of immigration on the structure of wages and employment: theory and evidence from Britain', working paper, August.

Nickell, S.J. and J. Saleheen (2008), 'The impact of immigration on occupational wages: British evidence', working paper, April.

OECD (2006), International Migration Outlook. Annual Report, 2006 Edition. Paris 
Office of National Statistics (2008), 'International Migration', Series MN No. 332006 data.

Pedersen, P.J. M. Pytlikova and N. Smith (2004), 'Selection or network effects? Migration flows into 27 OECD countries, 1990-2000', April, IZA Bonn, Discussion Paper No 1104.

Pollard, N., M. Latorre and D. Sriskandarajah (2008), 'Floodgates or turnstiles? Post-EU enlargement migration flows to (and from) the UK', IPPR, London, April.

Sachdev, D. and B. Harries (2006), 'Learning and skills planning and provision for migrants from the accession states - an exploratory study', Learning and Skills Council downloadable at www.lsneducation.org.uk.

Sanz de Galdeano, A. and J. Turunen (2006), 'The Euro area wage curve', Economics Letters, 92: pp. 93-98.

Yang, D. (2006), 'Why do migrants return to poor countries? Evidence from Philippine migrants' responses to exchange rate shocks', Review of Economics \& Statistics, November, 88(4), pp. 715-735.

Zaiceva, A. (2006), 'Reconciling the estimates of potential migration into the enlarged European Union', IZA Bonn, Discussion Paper No. 2519 
Table 1: Worker Registration Scheme Approvals, Re-registrations and National Insurance Number Applications, May 2004 - March 2008

$\begin{array}{rrccr} & \begin{array}{c}\text { Worker } \\ \text { Registration } \\ \text { Scheme }\end{array} & \text { Re-registrations } & \begin{array}{c}\text { Multiple } \\ \text { Re-registrations }\end{array} & \begin{array}{c}\text { National } \\ \text { Insurance } \\ \text { Number }\end{array} \\ \text { 2004 Total } & \mathbf{1 2 5 , 8 8 0} & \mathbf{1 0 , 1 3 0} & \mathbf{3 , 8 5 5} & \mathbf{6 2 , 5 3 9} \\ \text { 2005 Total } & \mathbf{2 0 4 , 9 7 0} & \mathbf{5 1 , 3 6 0} & \mathbf{1 3 , 9 4 5} & \mathbf{2 1 8 , 5 2 1} \\ \text { 2006 Total } & \mathbf{2 2 7 , 8 7 5} & \mathbf{8 1 , 8 4 5} & \mathbf{2 3 , 1 0 5} & \mathbf{2 6 0 , 9 0 9} \\ \text { 2007 Total } & \mathbf{2 1 0 , 5 7 5} & \mathbf{1 1 5 , 6 4 0} & \mathbf{1 9 , 8 7 0} & \mathbf{2 4 6 , 9 2 3} \\ \mathbf{2 0 0 7} \text { Q1 } & 50,315 & 28,370 & 6,090 & 68,782 \\ \text { Q2 } & 52,340 & 30,025 & 5,430 & 55,592 \\ \text { Q3 } & 57,270 & 29,295 & 4,475 & 66,281 \\ \text { Q4 } & 50,650 & 27,955 & 3,880 & 55,638 \\ \text { 2008 Q1 } & 42,790 & 32,700 & 4,205 & 52,858 \\ \text { Total } & \mathbf{8 1 2 , 0 9 0} & \mathbf{4 0 7 , 3 2 0} & \mathbf{6 4 , 9 8 0} & \mathbf{8 4 1 , 1 2 0}\end{array}$

Source: Accession Monitoring Report: May 2004 - March 2008. Home Office UK Border Agency

http://www.ukba.homeoffice.gov.uk/sitecontent/documents/aboutus/reports/accession_m onitoring_report/

Notes: the National Insurance Numbers reported here relate to the numbers allocated for employment purposes. A further 6,597 were allocated for benefit purposes and 13,998 for tax credit purposes. 
Table 2: Nationality of approved WRS applicants, by quarter and year of application, May 2004-March 2008

\begin{tabular}{|c|c|c|c|c|c|c|c|c|c|}
\hline & $\begin{array}{l}\text { Czech } \\
\text { Rep. }\end{array}$ & Estonia & Hungary & Latvia & Lithuania & Poland & Slovakia & Slovenia & Total \\
\hline 2005 Total & 10,575 & 2,560 & 6,355 & 12,960 & 22,990 & 127,325 & 22,035 & 175 & 204,970 \\
\hline 2007 Q1 & 1,825 & 275 & 1,965 & 1,835 & 3,740 & 35,800 & 4,835 & 45 & 50,315 \\
\hline Q2 & 1,800 & 210 & 2,085 & 1,630 & 3,690 & 37,280 & 5,600 & 40 & 52,340 \\
\hline Q3 & 1,985 & 275 & 2,305 & 1,545 & 3,715 & 41,170 & 6,230 & 50 & 57,270 \\
\hline 2008 Q1 & 1,585 & 175 & 2,435 & 1,280 & 2,520 & 29,790 & 4,965 & 45 & 42,790 \\
\hline Total & 36,260 & 7,035 & 28,335 & 38,680 & 76,080 & 540,755 & 84,200 & 755 & 812,090 \\
\hline$\%$ & $4 \%$ & $1 \%$ & $3 \%$ & $5 \%$ & $9 \%$ & $67 \%$ & $10 \%$ & $0 \%$ & $100 \%$ \\
\hline
\end{tabular}

Source: Accession Monitoring Report: May 2004 - March 2008. Home Office UK Border Agency

http://www.ukba.homeoffice.gov.uk/sitecontent/documents/aboutus/reports/accession_monitoring_report/ 
Table 3. Labour market characteristics (ages 16-70)

\begin{tabular}{|c|c|c|c|c|c|c|}
\hline & (1) & (2) & (3) & (4) & (5) & (6) \\
\hline & Work & Self- & Usual hours & Work limiting & Log hourly & Union \\
\hline & & Employment & & Health problem & Earnings & Membership \\
\hline New A10 & .0958 (16.76) & $-.0128(2.19)$ & 3.8890 (21.52) & $-.0563(12.61)$ & -.1342 (8.69) & $-.1160(5.26)$ \\
\hline Old A10 & .0409 (3.63) & 1992 (16.70) & $1.5946(4.66)$ & $-.0402(5.07)$ & $-.0412(1.21)$ & $-.0468(1.18)$ \\
\hline New Non-A10 & $-.0266(4.90)$ & $-.0581(11.45)$ & 1.0992 (6.33) & $-.0464(11.25)$ & $.0637(4.41)$ & -.1097 (5.85) \\
\hline Old Non-A10 & $-.0053(1.93)$ & $.0213(8.57)$ & $.7840(9.40)$ & $-.0012(0.65)$ & .0337 (4.71) & $-.0294(3.37)$ \\
\hline Age & .0209 (73.55) & $.0094(31.85)$ & 1.0930 (116.21) & $.0014(6.60)$ & .0610 (74.92) & .0221 (19.99) \\
\hline Age $^{2}$ & -.0002 (82.37) & -.00007 (19.67) & $-.0132(117.50)$ & $.0000(1.45)$ & $-.0006(65.41)$ & -.0002 (17.19) \\
\hline Male & .0933 (71.99) & .0917 (79.78) & $7.7264(180.27)$ & $.0039(3.86)$ & $.1582(44.16)$ & $.0454(9.84)$ \\
\hline Degree & .2232 (136.07) & $-.0171(8.37)$ & 3.1057 (39.17) & -.0365 (23.59) & 6972 (101.73) & .0832 (8.99) \\
\hline Higher education & .1825 (99.08) & $-.0280(12.14)$ & 1.6972 (19.07) & $-.0191(10.96)$ & $.4597(60.69)$ & $.0916(8.80)$ \\
\hline Apprenticeship etc & .1896 (113.91) & $.0016(0.81)$ & $1.3460(17.76)$ & $-.0180(11.89)$ & $.2874(43.36)$ & $.0431(4.87)$ \\
\hline GCSE A-C & .1552 (90.57) & $-.0250(12.08)$ & $.6404(8.35)$ & $-.0160(10.37)$ & 1789 (27.09) & $.0079(0.90)$ \\
\hline Other qualifications & .1265 (67.56) & $-.0299(13.68)$ & $1.3504(16.04)$ & $-.0072(4.23)$ & $.1144(15.70)$ & $.0248(2.55)$ \\
\hline Don't know & $.1422(26.55)$ & $.0018(0.30)$ & $4.1166(17.13)$ & $-.0357(7.78)$ & $.1593(6.74)$ & $-.0077(0.27)$ \\
\hline Mixed race & $-.0810(9.62)$ & $.0272(3.40)$ & $-.8899(3.57)$ & $.0261(4.08)$ & $-.0368(1.75)$ & $-.0099(0.36)$ \\
\hline Asian & $-.1172(29.64)$ & $.0298(8.30)$ & $-1.0916(9.35)$ & $.0026(0.90)$ & $-.1470(14.25)$ & $-.0083(0.64)$ \\
\hline Black & $-.0698(13.75)$ & $-.0421(10.23)$ & $-1.2605(8.39)$ & $-.0079(2.23)$ & $-.2005(15.37)$ & $.0404(2.38)$ \\
\hline Chinese & $-.0348(3.25)$ & $.0248(2.64)$ & $-.2477(0.79)$ & $-.0215(2.86)$ & $-.1323(4.79)$ & $-.1068(3.25)$ \\
\hline Other race & $-.1110(18.04)$ & $-.0090(1.70)$ & $-.9581(5.21)$ & $-.0012(0.27)$ & $-.1717(10.54)$ & $-.0204(0.95)$ \\
\hline Self-employed & & & $2.5554(40.85)$ & $.0122(8.65)$ & & \\
\hline Region dummies (19) & Yes & Yes & Yes & Yes & Yes & Yes \\
\hline Industry dummies (61) & No & No & No & Yes & Yes & Yes \\
\hline Organisn dummies (8) & No & No & Yes & Yes & Yes & Yes \\
\hline $\mathrm{R}^{2} /$ Pseudo $\mathrm{R}^{2}$ & .1275 & .0688 & .2549 & .0334 & .3988 & .2398 \\
\hline $\mathrm{N}$ & 445,462 & 329,037 & 321,192 & 326,746 & 83,193 & 48,232 \\
\hline
\end{tabular}

Source: LFS December 2006-March 2008. Notes: equations also include three year dummies. Excluded categories no qualification; white. Workers only in columns 2-6 and excludes students in column 1. Columns 1, 2, 4 and 6 are dprobits and columns 3 and 5 are OLS. 'New A10' and 'New NonA10' means they arrived post 2003 and 'Old A10' and 'Old Non-A10' means they arrived post 2003. T-statistics in parentheses. 
Table 4. Difficulty in finding a job and job satisfaction, 2005

Czech Republic

East Germany

Estonia

Hungary

Latvia

Lithuania

Poland

Slovakia

Slovenia

Austria

Belgium

Cyprus

Denmark

Finland

France

Greece

Ireland

Italy

Luxembourg

Malta

Netherlands

Portugal

Spain

Sweden

West Germany

Age

Age $^{2}$

Male

15-19 years schooling

\section{Difficult to}

find a job

Ordered logit

1.1605 (14.48)

$2.4117(21.26)$

.9161 (11.37)

2.4462 (26.93)

$1.0884(13.60)$

1.5810 (19.09)

1.9012 (22.51)

$1.6820(20.86)$

$1.3586(17.24)$

.8507 (10.73)

$.2413(3.10)$

1.3743 (13.44)

-.8675 (10.60)

$-.1691(2.15)$

$.6294(8.00)$

1.9041 (22.45)

$-.4873(6.05)$

1.1609 (14.59)

.6009 (6.06)

$.6283(6.29)$

.0531 (0.67)

1.8364 (21.72)

-.2404 (2.96)

1.5858 (19.61)

Difficult to

find a job

Ordered logit

1.1468 (10.23)

2.4252 (14.11)

.9057 (7.70)

2.7023 (18.38)

1.0293 (8.98)

1.3793 (11.08)

1.7601 (13.01)

1.6443 (14.48)

1.3459 (11.45)

.8731 (7.81)

.0392 (0.35)

1.3987 (9.65)

$-1.2644(10.87)$

-.3461 (2.98)

.5513 (4.85)

2.0568 (15.87)

-.4563 (3.95)

1.1547 (10.08)

.5002 (3.31)

.7514 (4.39)

$-.0647(0.60)$

1.9446 (14.92)

1.4493 (11.62)

$-.5252(4.72)$

1.6019 (13.83)

$-.0028(2.52)$

.0019 (1.20)

-.1866 (6.98)

$-.2471(6.69)$
1.3948 (16.99)
Salary

Ordered logit

-.6714 (5.70)

$-.6379(3.96)$

$-.7641(6.24)$

-1.5834 (12.11)

-1.3954 (11.69)

-1.2300 (9.52)

-1.1206 (8.11)

-.8669 (7.26)

-.4575 (3.68)

.5020 (4.17)

.1935 (1.59)

-.1031 (0.67)

.7648 (6.16)

-.3650 (2.89)

$-.9238(7.60)$

-.4027 (3.04)

.3767 (3.03)

$-.3870(3.16)$

.9350 (5.62)

-.6968 (3.77)

.4205 (3.58)

$-.7338(5.54)$

-.2069 (1.57)

-.3896 (3.35)

$-.0126(0.10)$

-.0450 (4.36)

.0005 (4.19)

.2843 (7.17)

$.0076(0.12)$
Job satisfaction

\# hours Work life balance All Ordered logit Ordered logit OLS -.3049(2.64) - -.1360 (1.17) -1.3419 (4.53)

-.0969(0.60) .1661(1.02) $-1.1292(2.75)$

$-.0883(0.73) \quad-.1815(1.49)-1.8504(5.97)$

$-.5317(4.03) \quad-.2605(1.95)-2.9140(9.09)$

$-.3385(2.87) \quad-.6546(5.49)-2.9984(10.24$

$-.4994(3.89) \quad-.2647(2.08)-2.5145(7.82)$

$-.3936(2.85) \quad-.3796(2.75)-2.3754(6.38)$

$-.5163(4.43) \quad-.3073(2.63)-2.4399(8.33)$

$-.5144(4.23) \quad-.3774(3.09)-1.8955(6.40)$

$.0432(0.37) \quad .6176(5.28) \quad .9651(3.34)$

$.2949(2.49) \quad .1625(1.36) \quad .0294(0.10)$

-.4133(2.79) $\quad .0640(0.44)-1.4760(3.68)$

$.9793(8.08) \quad 1.0672(8.73) \quad 2.2686(7.75)$

$\begin{array}{lll}-.1431(1.18) \quad .0989(0.80) & -1.2530(3.75)\end{array}$

$-.4335(3.60) \quad-.1346(1.11) \quad-.8758(2.91)$

$-.2363(1.81) \quad-.1254(0.97)-1.8999(6.24)$

$.3253(2.69) \quad .4002(3.31) \quad .4441(1.46)$

$-.5361(4.54) \quad-.2331(1.95) \quad-2.7680(9.28)$

$.9203(5.70) \quad .4335(2.68) \quad 1.1058(2.77)$

$.3424(1.87) \quad .0003(0.00)-1.5257(3.22)$

$.6465(5.65) \quad .3869(3.37) \quad .5856(2.08)$

-..3918 (3.06) $\quad-.0786(0.61)-2.0299(6.18)$

$-.4322(3.38) \quad-.0051(0.04)-1.6260(5.18)$

$.1224(1.07) \quad .1439(1.25) \quad-.6336(2.24)$

$.1045(0.88) \quad .1716(1.43) \quad-.5072(1.72)$

$-.0405(4.02) \quad-.0575(5.62) \quad-.1065(4.07)$

$.0005(4.50) \quad .0007(6.65) \quad .0014(4.76)$

$\begin{array}{lll}-.1177(3.00) & -.0060(0.15) & .0367(2.40)\end{array}$

$.0006(0.01) \quad-.1201(1.86) \quad-.0500(0.30)$ 


\begin{tabular}{|c|c|c|c|c|c|c|}
\hline$\geq 20$ years schooling & $-.5455(12.85)$ & $-.4874(6.93)$ & $.0879(1.22)$ & $-.0099(0.14)$ & $-.2245(3.13)$ & $.0271(0.15)$ \\
\hline Minority & $.2285(4.22)$ & $.3083(4.03)$ & $-.3400(4.30)$ & $-.0760(0.97)$ & $-.0962(1.23)$ & $-.6375(3.21)$ \\
\hline Student & $-.6518(8.85)$ & & & & & \\
\hline Unemployed & $.6413(9.25)$ & & & & & \\
\hline Retired & $.0327(0.62)$ & & & & & \\
\hline Professional & $-.5767(5.36)$ & $-.3737(2.33)$ & $1.3177(7.86)$ & 1.4279 (8.59) & .6337 (3.79) & $2.6202(4.94)$ \\
\hline Shop owner & $-.2270(2.60)$ & $-.0284(0.20)$ & 1.0409 (6.98) & .9235 (6.24) & $.4893(3.27)$ & $2.3728(4.69)$ \\
\hline usiness proprietor & $-.6405(6.14)$ & $-.4236(2.70)$ & $1.5541(9.52)$ & $1.0957(6.81)$ & $.6874(4.22)$ & $3.1334(5.96)$ \\
\hline mployed professional & $-.7373(8.53)$ & $-.5175(3.52)$ & $1.0092(6.72)$ & $1.3974(9.27)$ & $.5381(3.54)$ & $1.6144(3.33)$ \\
\hline General management & $-.7789(6.34)$ & $-.5510(3.23)$ & $1.8943(10.60)$ & $1.2970(7.30)$ & $.4995(2.80)$ & $2.6514(5.00)$ \\
\hline Middle management & $-.5122(7.78)$ & $-.2783(2.05)$ & $1.0878(7.85)$ & $1.5037(10.82)$ & $.5782(4.11)$ & $1.5339(3.32)$ \\
\hline Employed - desk & $-.2242(3.70)$ & $.0056(0.04)$ & $.8406(6.20)$ & 1.6613 (12.19) & $.6362(4.62)$ & $1.0896(2.38)$ \\
\hline Traveling salesman & $-.1980(2.33)$ & $.0647(0.45)$ & $.6266(4.30)$ & $1.1060(7.58)$ & $.1828(1.24)$ & $.0680(0.14)$ \\
\hline Employed not at a desk & $-.2492(3.88)$ & $.0033(0.03)$ & $.5937(4.35)$ & $1.3769(10.02)$ & $.5156(3.71)$ & $.6522(1.42)$ \\
\hline Supervisor & $-.3656(2.60)$ & $-.0960(0.52)$ & 1.0255 (5.33) & $1.5588(8.26)$ & .5989 (3.13) & $1.4063(2.50)$ \\
\hline Skilled manual & $-.0080(0.13)$ & .2604 (1.98) & .5275 (3.98) & $1.2623(9.49)$ & $.3478(2.58)$ & $-.1703(0.38)$ \\
\hline Unskilled manual & $.1334(1.71)$ & .3703 (2.62) & $.4115(2.90)$ & $1.2545(8.81)$ & .3369 (2.33) & $-.7355(1.55)$ \\
\hline cut1/constant & -2.4404 & -2.1081 & -2.9094 & -2.7471 & -4.0367 & 32.6511 \\
\hline cut2 & -.7100 & -.3220 & -1.2209 & -1.1085 & -2.2257 & \\
\hline cut3 & .8844 & 1.2653 & 1.6827 & 1.4604 & .3257 & \\
\hline Workers only & No & Yes & Yes & Yes & Yes & Yes \\
\hline $\mathrm{N}$ & 23,954 & 11,127 & 11,134 & 11,151 & 11,115 & 9,188 \\
\hline Pseudo/Adj R ${ }^{2}$ & .1012 & .1101 & .0609 & .0336 & .0231 & .1340 \\
\hline Source: Eurobarometer \#6 & Food Risk, & AIDS Preve & .0000 & tember-Octol & (ICPSR 46 & Notes: excluded \\
\hline
\end{tabular}


Table 5: Job satisfaction, job security and the likelihood of being replaced, 2005

\begin{tabular}{|c|c|c|c|}
\hline & Job satisfaction & Job security & $\begin{array}{c}\text { Easy to Replace } \\
.9985(8.30)\end{array}$ \\
\hline $\begin{array}{l}\text { Bulgaria } \\
\text { Czech Republic }\end{array}$ & $\begin{array}{l}-.1965(1.63) \\
-.4521(4.03)\end{array}$ & $\begin{array}{l}-.8219(7.04) \\
-.5342(5.01)\end{array}$ & $\begin{array}{l}.9985(8.30) \\
.7196(6.46)\end{array}$ \\
\hline East Germany & $1898(1.37)$ & $-.4336(3.17)$ & $1058(0.75)$ \\
\hline Hungary & $-.3305(2.65)$ & $-.3633(3.08)$ & $.3348(2.73)$ \\
\hline Latvia & $-.1673(1.32)$ & $-.4289(3.46)$ & $-.2721(2.13)$ \\
\hline Russia & $-.4404(4.04)$ & $.0072(0.07)$ & .4878 (4.65) \\
\hline Slovenia & $-.4606(3.85)$ & $.4020(3.42)$ & .1315 (1.12) \\
\hline Australia & $-.3047(3.00)$ & $-.2052(2.09)$ & 1789 (1.78) \\
\hline Canada & -.1259 (1.08) & $-.0997(0.87)$ & 2886 (2.49) \\
\hline Cyprus & $.9777(7.75)$ & $-.1224(1.00)$ & .7440 (5.67) \\
\hline Denmark & $.2724(2.63)$ & .4700 (4.58) & $-.0716(0.70)$ \\
\hline Dominican Republic & 1546 (1.47) & .1512 (1.49) & $1.2832(11.90)$ \\
\hline Finland & $-.0972(0.89)$ & $-.2926(2.70)$ & $.1166(1.05)$ \\
\hline Flanders & $-.4811(4.46)$ & $-.1161(1.12)$ & $.0892(0.84)$ \\
\hline France & $-.5886(5.73)$ & $-.3827(3.74)$ & .6971 (6.85) \\
\hline Ireland & .5505 (4.77) & .3035 (2.67) & .4101 (3.49) \\
\hline Israel & $.2115(1.80)$ & $-.2189(1.92)$ & .2237 (1.92) \\
\hline Japan & $-.7262(6.18)$ & .1857 (1.51) & $.2314(1.92)$ \\
\hline Mexico & $1.0700(9.36)$ & .3568 (3.18) & $1.0513(8.74)$ \\
\hline New Zealand & -.1578 (1.49) & $.0240(0.23)$ & $-1365(1.30)$ \\
\hline Norway & $-.1857(1.76)$ & $-.2855(2.80)$ & $.2313(2.23)$ \\
\hline Philippines & .4397 (3.74) & .1179 (1.05) & $.8860(7.49)$ \\
\hline Portugal & $-.0374(0.36)$ & $-.0889(0.86)$ & $.5682(5.46)$ \\
\hline South Africa & $.2902(2.64)$ & $-.0425(0.40)$ & $.7716(6.96)$ \\
\hline South Korea & -1.1639 (11.02) & $-.8819(8.68)$ & $4163(3.90)$ \\
\hline Spain & $-.0617(0.53)$ & .2159 (1.88) & $.3344(2.90)$ \\
\hline Sweden & $-.2896(2.71)$ & $-.0963(0.93)$ & $.0813(0.77)$ \\
\hline Switzerland & $6848(6.21)$ & $.0172(0.16)$ & $.0522(0.47)$ \\
\hline Taiwan & $-.6054(6.11)$ & $-.4757(4.97)$ & .5297 (5.28) \\
\hline USA & $.2254(2.16)$ & $.1226(1.21)$ & .3218 (3.08) \\
\hline West Germany & 2047 (1.74) & $.3242(2.78)$ & $.0918(0.78)$ \\
\hline Age & .0106 (10.25) & $-.0255(4.24)$ & -.0191 (3.04) \\
\hline $\mathrm{Age}^{2}$ & & $.0003(4.94)$ & $.0001(2.55)$ \\
\hline Male & $-.0031(0.13)$ & $-.0706(2.83)$ & $-.2663(10.47)$ \\
\hline Lowest formal & 3959 (5.18) & $.1044(1.40)$ & $-.2731(3.36)$ \\
\hline Above lowest & $.4816(6.64)$ & $.1029(1.46)$ & $-.3509(4.57)$ \\
\hline higher secondary & $.6206(8.71)$ & $.2641(3.81)$ & $-.4347(5.78)$ \\
\hline Above higher sec. & .7277 (10.09) & $.3218(4.58)$ & $-.5740(7.54)$ \\
\hline Degree completed & $.7972(11.11)$ & $.5050(7.20)$ & $-.6075(8.01)$ \\
\hline Other qualification. & 1.4434 (1.49) & $.3123(0.34)$ & $.4312(0.51)$ \\
\hline Self-employed & .4917 (13.91) & $-.1205(3.44)$ & $-1.1464(28.55)$ \\
\hline Part time & $-.0289(0.83)$ & $-.2211(6.26)$ & $.2363(6.56)$ \\
\hline$<$ part-time & $-.0467(0.48)$ & $-.6727(7.06)$ & $.3718(3.81)$ \\
\hline Helping family member & $-.4492(3.45)$ & $.0081(0.06)$ & $-.3200(2.08)$ \\
\hline
\end{tabular}




$\begin{array}{lcrr}\text { cut1 } & -3.6753 & -3.4110 & -3.1686 \\ \text { cut2 } & -2.5910 & -1.8103 & -1.6748 \\ \text { cut3 } & -1.5238 & .9233 & -.5425 \\ \text { cut4 } & -.5438 & .8820 & .9037 \\ \text { cut5 } & 1.3103 & & \\ \text { cut6 } & 2.9072 & & \\ \mathrm{~N} & 23,221 & 23,066 & 21,707 \\ \text { Pseudo } \mathrm{R}^{2} & .0259 & .0148 & .0301\end{array}$

Notes: excluded categories UK, full-time and no formal qualification. T-statistics in parentheses. Ordered logits. The age squared variable was insignificant in column 1 and hence was omitted. Source: International Social Survey Programme, Work Orientation module, 2005

Questions. 1. How satisfied are you in your main job - completely satisfied (=7); very satisfied (=6); fairly satisfied (=5); neither satisfied nor dissatisfied (=4); fairly dissatisfied (=3); very dissatisfied (=2); completely dissatisfied (=1). 2. My job is secure - strongly agree (=4); agree (=3); neither agree nor disagree (=2); strongly disagree $(=1)$. 3 . How difficult or easy do you think it would be for your firm or organization to replace you if you left - very easy (=5); fairly easy (=4); neither easy nor difficult (=3); fairly difficult (=2); very difficult (=1). 
Table 6: Life satisfaction and percent reporting the next twelve months will be better, 2004 and 2007.

\begin{tabular}{|c|c|c|c|c|c|c|c|c|c|c|c|c|}
\hline & Life sa & faction & & & & Expec & tions 12 & months & ahead ( & better) & & \\
\hline & & & & & $\begin{array}{c}\text { Econ } \\
\text { Situ }\end{array}$ & $\begin{array}{l}\text { mic } \\
\text { ion }\end{array}$ & $\begin{array}{l}\text { Finar } \\
\text { Situa }\end{array}$ & & $\begin{array}{l}\text { Emp } \\
\text { Situ }\end{array}$ & $\begin{array}{l}\text { yment } \\
\text { ion }\end{array}$ & $\begin{array}{c}\text { Pers } \\
\text { Situ }\end{array}$ & $\begin{array}{l}\text { al job } \\
\text { ion }\end{array}$ \\
\hline & 2004 & 2007 & 2004 & 2007 & 2004 & 2007 & 2004 & 2007 & 2004 & 2007 & 2004 & 2007 \\
\hline Bulgaria & 2.06 & 2.15 & 25 & 26 & 24 & 26 & 19 & 24 & 23 & 30 & 35 & 20 \\
\hline Czech Republic & 2.82 & 2.91 & 17 & 22 & 9 & 18 & 8 & 19 & 8 & 27 & 26 & 18 \\
\hline Estonia & 2.74 & 2.80 & 39 & 40 & 39 & 30 & 32 & 35 & 35 & 32 & 14 & 35 \\
\hline Hungary & 2.44 & 2.38 & 24 & 15 & 19 & 14 & 20 & 12 & 17 & 10 & 26 & 11 \\
\hline Latvia & 2.52 & 2.68 & 31 & 34 & 26 & 21 & 27 & 31 & 27 & 32 & 26 & 33 \\
\hline Lithuania & 2.55 & 2.63 & 39 & 35 & 37 & 31 & 33 & 31 & 44 & 48 & 28 & 38 \\
\hline Poland & 2.81 & 2.85 & 35 & 30 & 26 & 33 & 21 & 25 & 23 & 40 & 17 & 20 \\
\hline Romania & 2.32 & 2.39 & 50 & 44 & 44 & 36 & 44 & 41 & 35 & 33 & 34 & 38 \\
\hline Slovakia & 2.59 & 2.74 & 24 & 29 & 18 & 24 & 18 & 22 & 24 & 33 & 18 & 22 \\
\hline Slovenia & 3.17 & 3.10 & 32 & 26 & 28 & 24 & 22 & 20 & 19 & 21 & 16 & 16 \\
\hline UK & 3.22 & 3.22 & 44 & 35 & 16 & 17 & 32 & 30 & 17 & 17 & 28 & 30 \\
\hline
\end{tabular}

Source: 2004 data from Eurobarometer \#62.0, Standard European Trend Questions and Sport, October-November, 2004 (ICPSR 4289). 2007 data from Eurobarometer \#68.1, 'Public Opinion in the European Union', September-November 2007.

Questions.

1. On the whole are you very satisfied (=4); fairly satisfied (=3), not very satisfied (=2) or not at all satisfied (=1) with the life you lead?

2. What are your expectations for the next twelve months: will the next twelve months be better, worse or the same, when it comes to...?

a) Your life in general

b) The economic situation in our country?

c) The financial situation of your household?

d) The employment situation in our country?

e) Your personal job situation? 
Table 7: Life satisfaction, important issues facing our country at the moment and views on the direction of the country, 2007

\begin{tabular}{|c|c|c|c|c|c|}
\hline & $\begin{array}{l}\text { Life } \\
\text { satisfaction }\end{array}$ & $\begin{array}{l}\text { Life } \\
\text { satisfaction (A10 only) }\end{array}$ & Unemployment & $\begin{array}{l}\text { Rising prices/ } \\
\text { Inflation }\end{array}$ & $\begin{array}{l}\text { Direction of } \\
\text { the country }\end{array}$ \\
\hline Bulgaria & $-2.5924(31.73)$ & $-1.9220(20.69)$ & $.2100(8.35)$ & .5615 (23.52) & $.1244(1.46)$ \\
\hline Czech Republic & $-.7988(10.18)$ & excluded category & 1040 (4.37) & .4590 (18.91) & $-.0441(0.55)$ \\
\hline Estonia & $-1.0884(13.63)$ & $-.3286(3.57)$ & $-.0118(0.49)$ & .5865 (25.49) & 1.0549 (12.22) \\
\hline Hungary & $-1.9342(24.33)$ & $-1.1318(12.42)$ & .4149 (16.94) & .3665 (14.53) & $-.8175(9.30)$ \\
\hline Latvia & $-1.4093(17.56)$ & $-.7179(7.84)$ & $.0774(3.25)$ & .6765 (32.10) & $-.3358(3.89)$ \\
\hline Lithuania & $-1.4972(18.54)$ & $-.7730(8.33)$ & $-.0360(1.54)$ & 6039 (26.53) & $.2910(3.44)$ \\
\hline Poland & $-.8328(10.09)$ & $-.0083(0.09)$ & $.3410(13.72)$ & $.2690(10.29)$ & $-.0559(0.65)$ \\
\hline Romania & $-2.1805(27.05)$ & $-1.4535(15.77)$ & $.1401(5.73)$ & .3947 (15.59) & $.6538(7.58)$ \\
\hline Slovakia & $-1.1815(15.00)$ & $-.4230(4.72)$ & .3265 (13.53) & .3691 (14.89) & $4678(5.90)$ \\
\hline Slovenia & $-.1373(1.68)$ & .7956 (8.11) & $.2180(8.83)$ & .6032 (26.52) & $.2721(3.26)$ \\
\hline Austria & $-.2412(3.02)$ & & $.3006(12.31)$ & .4363 (17.73) & $.7126(8.74)$ \\
\hline Belgium & $.1522(1.89)$ & & .3008 (12.28) & .4014 (16.06) & -.0651 (0.79) \\
\hline Croatia & $-.9222(11.01)$ & & $.5552(23.04)$ & $.0923(3.46)$ & $.0658(0.79)$ \\
\hline Cyprus & $-.2679(2.56)$ & & .1467 (4.95) & .4945 (17.41) & $-.2779(2.59)$ \\
\hline Denmark & $1.5762(18.13)$ & & $-.0709(2.84)$ & $.0307(1.12)$ & .9619 (10.98) \\
\hline East Germany & $-1.1793(11.65)$ & & $.5337(19.05)$ & .4750 (16.73) & $.2211(2.20)$ \\
\hline Finland & .1235 (1.54) & & $.2112(8.54)$ & $.2729(10.50)$ & $.6003(7.17)$ \\
\hline France & $-.6035(7.56)$ & & .4318 (17.78) & .3148 (12.39) & $.3984(4.78)$ \\
\hline Greece & $-1.4308(17.73)$ & & $.4446(18.11)$ & .3945 (15.66) & .0977 (1.18) \\
\hline Ireland & $.1907(2.34)$ & & $.0273(1.16)$ & .2326 (8.99) & $.6124(7.13)$ \\
\hline Italy & $-1.0781(13.21)$ & & $.3176(12.81)$ & $.3268(12.72)$ & $-.4434(5.21)$ \\
\hline Luxembourg & $.7526(7.23)$ & & $.3844(13.10)$ & .4187 (14.12) & $.8608(8.00)$ \\
\hline Macedonia & $-1.4983(17.65)$ & & $.6113(25.62)$ & .1635 (6.18) & .5554 (6.62) \\
\hline Malta & $-.3948(3.74)$ & & $.1308(4.48)$ & $.4427(15.16)$ & $.8870(8.44)$ \\
\hline Netherlands & .8062 (9.94) & & $-.0730(2.97)$ & $1298(4.88)$ & $.2793(3.44)$ \\
\hline Portugal & $-1.8310(22.89)$ & & $.5228(21.41)$ & $.3796(14.88))$ & -.1364 (1.59) \\
\hline Spain & $-.2872(3.43)$ & & $.1836(7.40)$ & $.1343(5.02)$ & $.5057(5.90)$ \\
\hline Sweden & $.6327(7.78)$ & & .2355 (9.39) & $-.0826(2.93)$ & .4516 (5.31) \\
\hline Turkey & $-.7104(7.85)$ & & $.5405(21.48)$ & $-.0917(3.31))$ & $.6681(7.04)$ \\
\hline West Germany & $-.2911(3.60)$ & & $.4695(19.40)$ & $.3561(14.12)$ & $.5924(7.20)$ \\
\hline Age & -.0696 (14.57) & $-.1024(11.96)$ & $-.0020(7.61)$ & $-.0013(4.66)$ & $.0005(0.47)$ \\
\hline
\end{tabular}




$\begin{array}{lc}\text { Age }^{2} & .0006(13.64) \\ \text { Male } & -.0554(2.15) \\ \text { ALS 16-19 } & .2679(7.91) \\ \text { ALS 20+ } & .5392(13.42) \\ \text { Still studying } & .7544(9.56) \\ \text { No FT education } & -.3677(1.57) \\ \text { Married } & .3493(7.62) \\ \text { Remarried } & .2635(2.84) \\ \text { Living together } & .0935(1.67) \\ \text { Past lived together } & -.3098(4.32) \\ \text { Divorced } & -.3293(5.18) \\ \text { Separated } & -.3480(3.37) \\ \text { Widowed } & -.3085(5.02) \\ \text { Native } & .0918(1.82) \\ \text { Centre voter } & .1389(4.44) \\ \text { Right-wing voter } & .3079(8.84) \\ \text { Unemployed } & -.7591(11.58) \\ \text { Retired } & -.1006(1.86) \\ \text { Farmer } & -.3292(3.17) \\ \text { Fisher } & -1.1623(1.80) \\ \text { Shop owner } & .3691(3.50) \\ \text { Business proprietor } & .0328(0.39) \\ \text { Employed professional } & .4607(4.47) \\ \text { General management } & .3244(3.73) \\ \text { Middle management } & .5456(4.25) \\ \text { Employed at a desk } & .3444(5.22) \\ \text { Employed traveling } & .1686(2.77) \\ \text { Service employee } & .1128(1.31) \\ \text { Supervisor } & .0862(1.36) \\ \text { Skilled manual } & .1018(0.73) \\ \text { Unskilled manual } & -.0844(1.42) \\ \text { Cut1 } & -5.0512 \\ \text { Cut2 } & -3.1644 \\ \text { Cut3 } & -.0695 \\ & \\ & \end{array}$

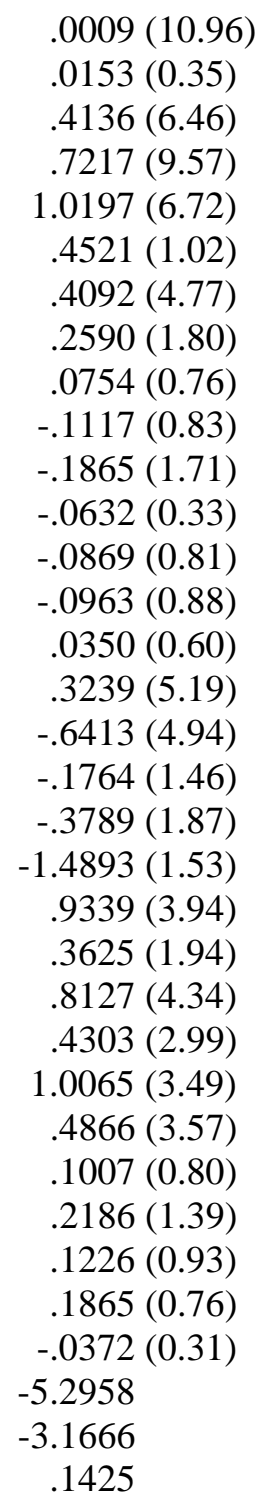

.1425

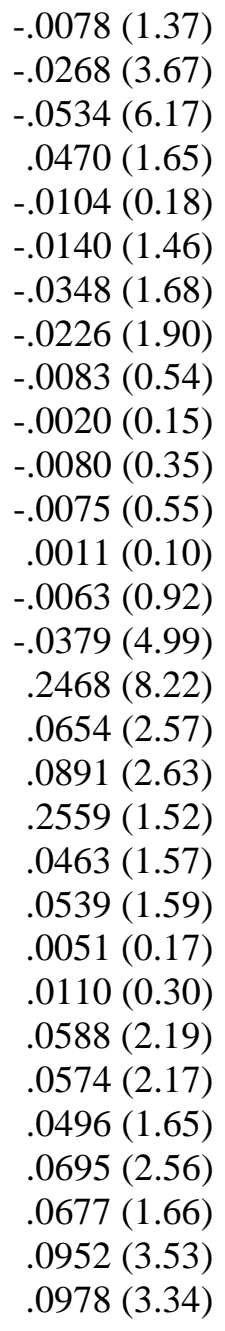

$$
\begin{array}{r}
-.0099(1.59) \\
-.0217(2.70) \\
-.0605(6.39) \\
-.0560(1.99) \\
.0597(0.92) \\
.0286(2.67) \\
.0384(1.70) \\
.0130(0.96) \\
-.0033(0.19) \\
.0260(1.71) \\
.0859(3.35) \\
.0362(2.39) \\
.0024(0.20) \\
-.0069(0.92) \\
-.0231(2.76) \\
.0327(1.17) \\
.0485(1.84) \\
.0546(1.54) \\
-.0403(0.23) \\
.0276(0.90) \\
.0101(0.30) \\
.0224(0.73) \\
.0143(0.37) \\
.0276(1.01) \\
.0474(1.75) \\
.0641(2.04) \\
.0715(2.55) \\
.1035(2.42) \\
.0647(2.37) \\
.0857(2.86)
\end{array}
$$

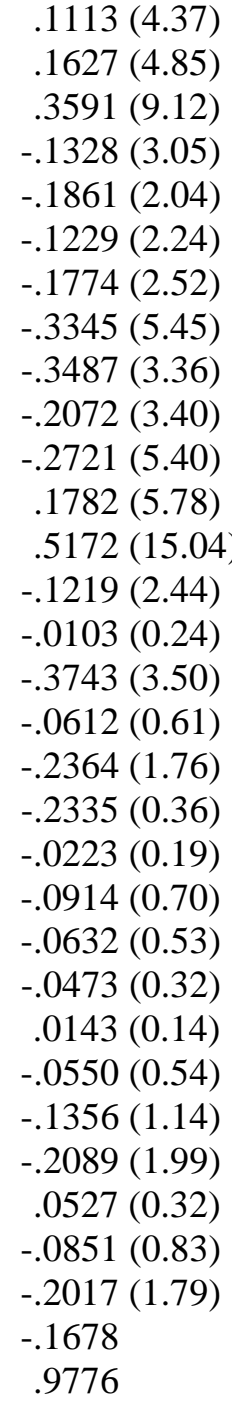




$\begin{array}{lccccc}\mathrm{N} & 29,061 & 9,800 & 28,759 & 28,759 & 27,406 \\ \text { Pseudo } \mathrm{R}^{2} & .1242 & .1075 & .1526 & .1380 & .0387\end{array}$

Source: Eurobarometer \#68.1, 'Public Opinion in the European Union', September-November 2007. Notes: excluded categories: UK; single; left-wing voter; responsible for shopping and age left school<16. Columns 3 and 4 dprobits; columns 1, 2 and 5 ordered logits. Life satisfaction - 1=not at all satisfied; $2=$ not very satisfied; 3=fairly satisfied and 4=very satisfied. Direction of country 1=wrong direction; 2=neither 3=right direction. T-statistics in parentheses. 
Table 8. Happy living in this country and likelihood of working or moving abroad, 2005/2006.

\begin{tabular}{|c|c|c|c|c|c|c|}
\hline & $\begin{array}{l}\text { Happy living } \\
\text { in this country } \\
\text { Ordered logit }\end{array}$ & $\begin{array}{l}\text { Worked } \\
\text { abroad } \\
\text { Dprobit }\end{array}$ & $\begin{array}{l}\text { Thinking of } \\
\text { working abroad } \\
\text { Dprobit }\end{array}$ & $\begin{array}{l}\text { Move next } \\
\text { five years } \\
\text { Dprobit }\end{array}$ & $\begin{array}{r}\text { Move } \\
\text { unempl } \\
\text { Dprol }\end{array}$ & $\begin{array}{l}\text { if } \\
\text { oyed } \\
\text { it }\end{array}$ \\
\hline East Germany & $-1.2213(11.86)$ & .0463 (3.05) & .0564 (2.79) & .0071 (0.89) & .0155 (0.75) & $-.0272(2.64)$ \\
\hline Estonia & $.4366(4.78)$ & $.0676(4.66)$ & .1277 (6.79) & $.0424(4.62)$ & .1015 (5.25) & $.0166(1.70)$ \\
\hline Hungary & $-2.1661(25.41)$ & $.0406(3.11)$ & .0645 (3.75) & $.0078(1.10)$ & .1007 (5.18) & .0133 (1.38) \\
\hline Latvia & $-.0667(0.76)$ & $.0491(3.70)$ & .1524 (8.19) & $.0387(4.44)$ & .2195 (10.07) & .0943 (7.98) \\
\hline Lithuania & $-.5185(6.02)$ & .0592 (4.18) & $.1582(8.17)$ & $.0550(5.53)$ & $.2506(10.85)$ & .1084 (8.63) \\
\hline Poland & $-.5193(6.09)$ & .0505 (3.73) & $.1322(7.10)$ & .0444 (4.73) & $.1462(7.09)$ & .0412 (3.86) \\
\hline Slovakia & -.9379 (11.33) & .0733 (5.08) & .1091 (6.28) & .0234 (2.83) & $.0680(3.68)$ & $-.0041(0.45)$ \\
\hline Slovenia & $-.2841(3.37)$ & .0682 (4.77) & .0157 (1.05) & $.0011(0.18)$ & $.0139(0.82)$ & $-.0263(3.21)$ \\
\hline Czech Republic & $-1.0654(12.78)$ & & & & & $-.0330(4.08)$ \\
\hline Austria & $.0954(1.09)$ & & & & & $-.0340(4.23)$ \\
\hline Belgium & $-.2103(2.44)$ & & & & & $.0049(0.54)$ \\
\hline Denmark & $1.6098(13.62)$ & & & & & $-.0187(2.22)$ \\
\hline Finland & $.6086(6.44)$ & & & & & $-.0354(4.47)$ \\
\hline France & $.0162(0.19)$ & & & & & $-.0384(4.74)$ \\
\hline Greece & $.2895(3.20)$ & & & & & $-.0395(5.02)$ \\
\hline Ireland & $.3072(3.40)$ & & & & & $-.0169(1.96)$ \\
\hline Italy & $-.7628(9.05)$ & & & & & $-.0117(1.31)$ \\
\hline Luxembourg & .8058 (6.32) & & & & & $-.0103(1.15)$ \\
\hline Malta & $.1180(1.04)$ & & & & & $-.0163(1.48)$ \\
\hline Netherlands & $-.1022(1.18)$ & & & & & $.0882(5.74)$ \\
\hline Portugal & $-.8642(10.11)$ & & & & & $-.0157(1.83)$ \\
\hline Spain & $.1353(1.53)$ & & & & & $-.0094(1.00)$ \\
\hline Sweden & 1.2625 (11.37) & & & & & $-.0395(5.06)$ \\
\hline West Germany & $-.8035(9.54)$ & & & & & $-.0177(2.07)$ \\
\hline Age & $.0150(10.17)$ & $-.0006(3.32)$ & $-.0056(14.59)$ & $-.0009(6.42)$ & $-.0017(5.22)$ & -.0007 (4.59) \\
\hline Male & $-.1559(5.33)$ & $.0202(5.54)$ & $.0338(4.90)$ & .0058 (2.39) & $.0236(3.70)$ & $.0157(4.84)$ \\
\hline 15-19 years schooling & $.0634(1.58)$ & .0025 (0.39) & $-.0027(0.19)$ & $.0086(1.54)$ & $.0122(1.18)$ & $.0047(1.01)$ \\
\hline
\end{tabular}




\begin{tabular}{|c|c|c|c|c|c|c|}
\hline$\geq 20$ years schooling & $.0577(1.21)$ & $.0036(0.50)$ & $.0158(0.98)$ & $.0185(2.47)$ & $.0356(2.83)$ & .0189 (3.39) \\
\hline Student & $.3261(3.74)$ & $-.0119(1.29)$ & .1409 (4.50) & $.0049(0.58)$ & $.0429(1.82)$ & $.0322(2.96)$ \\
\hline Unemployed & $-.4016(5.63)$ & $.0066(0.68)$ & .0977 (4.21) & $-.0012(0.23)$ & $.0001(0.01)$ & $-.0031(0.39)$ \\
\hline Retired & $.0809(1.34)$ & $-.0142(1.57)$ & $-.0104(0.51)$ & $-.0119(1.91)$ & $.0240(1.32)$ & $.0106(1.47)$ \\
\hline Farmer & $-.0897(0.63)$ & $.0050(0.29)$ & $.0220(0.57)$ & $-.0074(0.71)$ & $-.0005(0.02)$ & $-.0119(0.78)$ \\
\hline Professional & $-.1964(1.65)$ & $.0051(0.32)$ & $.0738(1.91)$ & $.0027(0.26)$ & $.0198(0.60)$ & $.0193(1.40)$ \\
\hline Shop owner & $-.0861(0.92)$ & -.0083 (0.69) & $.0381(1.23)$ & $-.0084(1.12)$ & $.0402(1.38)$ & $.0217(1.87)$ \\
\hline Business proprietor & $-.0126(0.11)$ & $.0093(0.66)$ & .1354 & -.008 & .0269 & $.0067(0.51)$ \\
\hline Employed professional & $.0968(0.97)$ & $.0013(0.12)$ & $.0899(3.36)$ & $-.0058(1.05)$ & $.0123(0.61)$ & .0069 (0.67) \\
\hline General management & $.3257(2.35)$ & $.0093(0.49)$ & $.0895(2.01)$ & $0.15)$ & .0017 & $.0021(0.14)$ \\
\hline Middle management & .1654 & -.0016 & .0565( & -.01 & -.0018 & $0.06)$ \\
\hline Employed - desk & .0645 & -.0071 & .0794 & -.01 & .0148 & $0.77)$ \\
\hline ling salesman & $.0446(0.46)$ & .0025 & .1063 & -.01 & .01 & $0.48)$ \\
\hline Employed no & .0865 & -.0092 & .0762 & -.01 & -.000 & 09) \\
\hline Supervisor & .208 & -.0054 & .1689 & .01 & .00 & $0.40)$ \\
\hline d manua & $-.1279(1.93)$ & .0017 (0.19) & .0855 & -.00 & .0089 & $.0067(0.84)$ \\
\hline Unskilled manual & .0852 (1.03) & $-.0067(0.71)$ & .0450 (1.83) & -.01 & .0073 & $.0025(0.26)$ \\
\hline Married & .0529 & -.0083 & -.0240 & -.00 & .00 & .0061 \\
\hline Remarried & $-.2888(2.76)$ & $.0032(0.27)$ & $-.0342(1.52)$ & .00 & .014 & $.0313(2.51)$ \\
\hline Living as mar & $-.0322(0.52)$ & $.0093(1.34)$ & $-.0047(0.39)$ & -.00 & $2.36)$ & .0051 (0.77) \\
\hline Pres & $-.3397(4.50)$ & .000 & & & .29) & $2(0.63)$ \\
\hline Divorced & $-.3627(5.26)$ & .0053 & .0240 & & .044 & $.0186(2.21)$ \\
\hline Separated & $-.4579(4.21)$ & $.0135(0.90)$ & $-.0142(0.54)$ & .01 & .0033 & $.0052(0.42)$ \\
\hline Widowed & $-.1128(1.59)$ & $-.0067(0.77)$ & $.0071(0.35)$ & $-.0055(0.82)$ & $-.0138(0.88)$ & $-.0102(1.28)$ \\
\hline Owns a computer & $.0440(1.30)$ & & & & & \\
\hline Owns a car & $.2387(7.01)$ & & & & & \\
\hline Private renter & & & & .01 & .0027 & $(2.22)$ \\
\hline Rural area & .1656 (4.65) & $-.0046(1.15)$ & $-.0114(1.39)$ & $-.0168(6.24)$ & $-.0205(2.82)$ & $-.0116(3.11)$ \\
\hline Small or middle sized town & 1349 (3.92) & $-.0046(1.19)$ & $.0170(2.16)$ & $-.0070(2.92)$ & $-.0209(3.00)$ & $-.0126(3.42)$ \\
\hline $\begin{array}{l}\text { \# children aged }<10 \text { years } \\
\text { cut1 }\end{array}$ & $\begin{aligned} .0776(3.46) \\
-3.2865\end{aligned}$ & $-.0025(0.98)$ & $-.0032(0.65)$ & $-.0036(1.87)$ & $-.0019(0.38)$ & $-.0037(1.51)$ \\
\hline
\end{tabular}




\begin{tabular}{lc|cc|c|cc} 
cut2 & -1.7470 & & & & \\
cut3 & .5242 & & & & \\
East Europe only & No & \multicolumn{2}{|c|}{ Yes } & Yes & Yes & Yes \\
$\mathrm{N}$ & 24,539 & 8,544 & 8,268 & 8,685 & 8,189 & 23,317 \\
Pseudo R ${ }^{2}$ & .0880 & .0795 & .2520 & .2173 & .1295 & .0789
\end{tabular}

Source: Columns 1-3: Eurobarometer \#65.1 - The Future of Europe, Consumer Protection in Trans Border Purchases, Family Planning, February-March 2006: (ICPSR 20321). Columns 4 and 5: Eurobarometer \#64.1: Mobility, Food Risk, Smoking, AIDS Prevention, and Medical Errors, September-October 2005 (ICPSR 4641).

Notes: excluded categories UK; responsible for shopping: single never lived with a partner and $<16$ years schooling. Czech Republic excluded category in columns 2-5. T-statistics in parentheses.

Question 1 (column 1). Please tell me if you agree or disagree with the following statement: you are happy living in your country 4=totally agree; $3=$ tend to agree; $2=$ tend to disagree and $1=$ totally disagree.

Question 2 (columns 2 and 3). Have you, yourself, ever considered living in another Member State in order to work? 1=Yes you have already done it: 2=yes you think of it but you haven't decided yet; 3=yes you have already thought of it but gave up the idea; 4=no you have never thought of it. Column 2 dependent variable set $=1$ if 1 and zero otherwise. Column 3 dependent variable set to one if thinking about working abroad zero otherwise with those who already worked abroad set to missing.

Question 3 (Column 4) Do you think that in the next five years you are likely to move to another country in the European Union?

Question 4 (Column 5) If you were unemployed and had difficulties finding a new job, would you be ready to move to another country to find

one? 

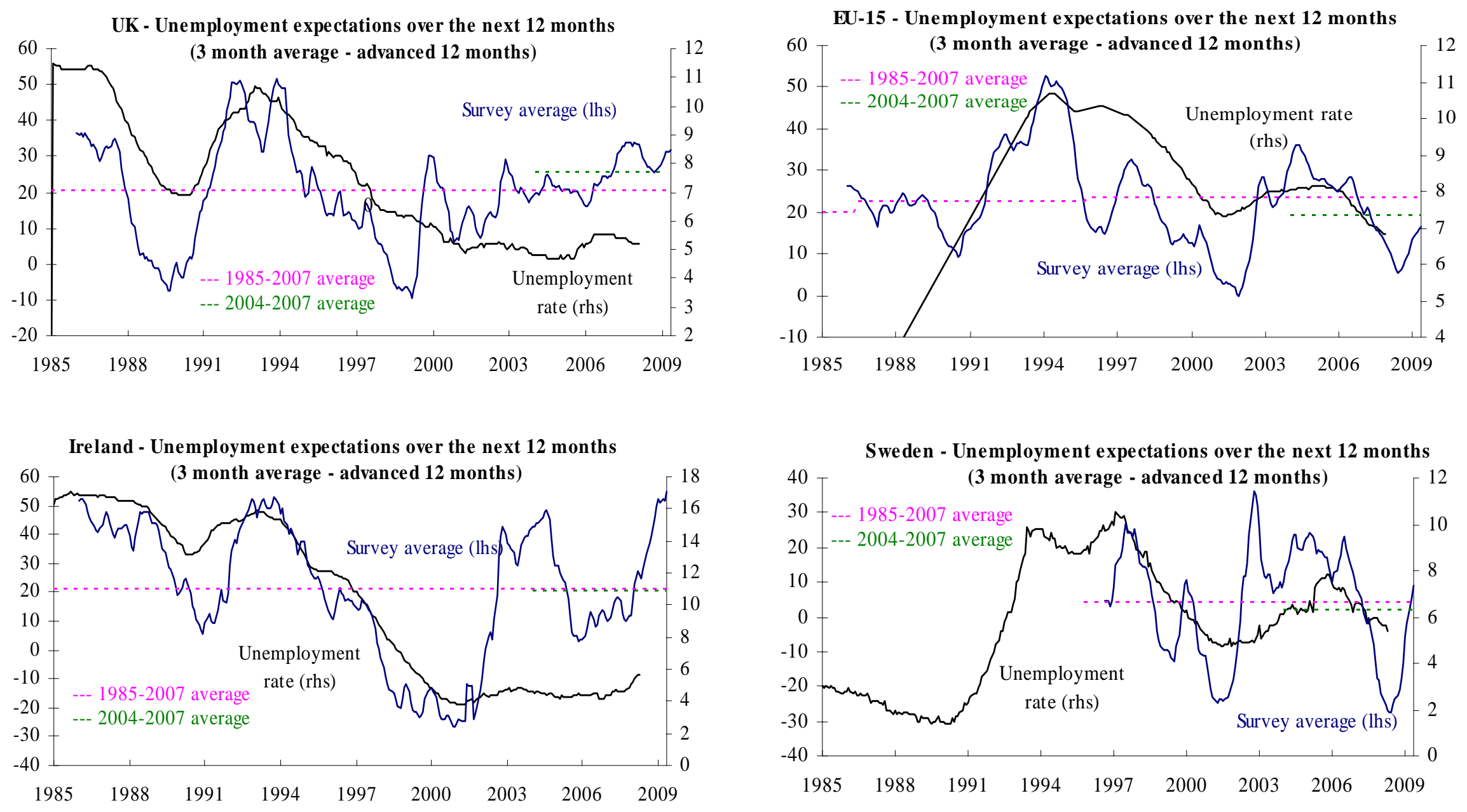


\section{Chart 2: Annual growth of LFS whole economy hourly pay ${ }^{(a)}$}

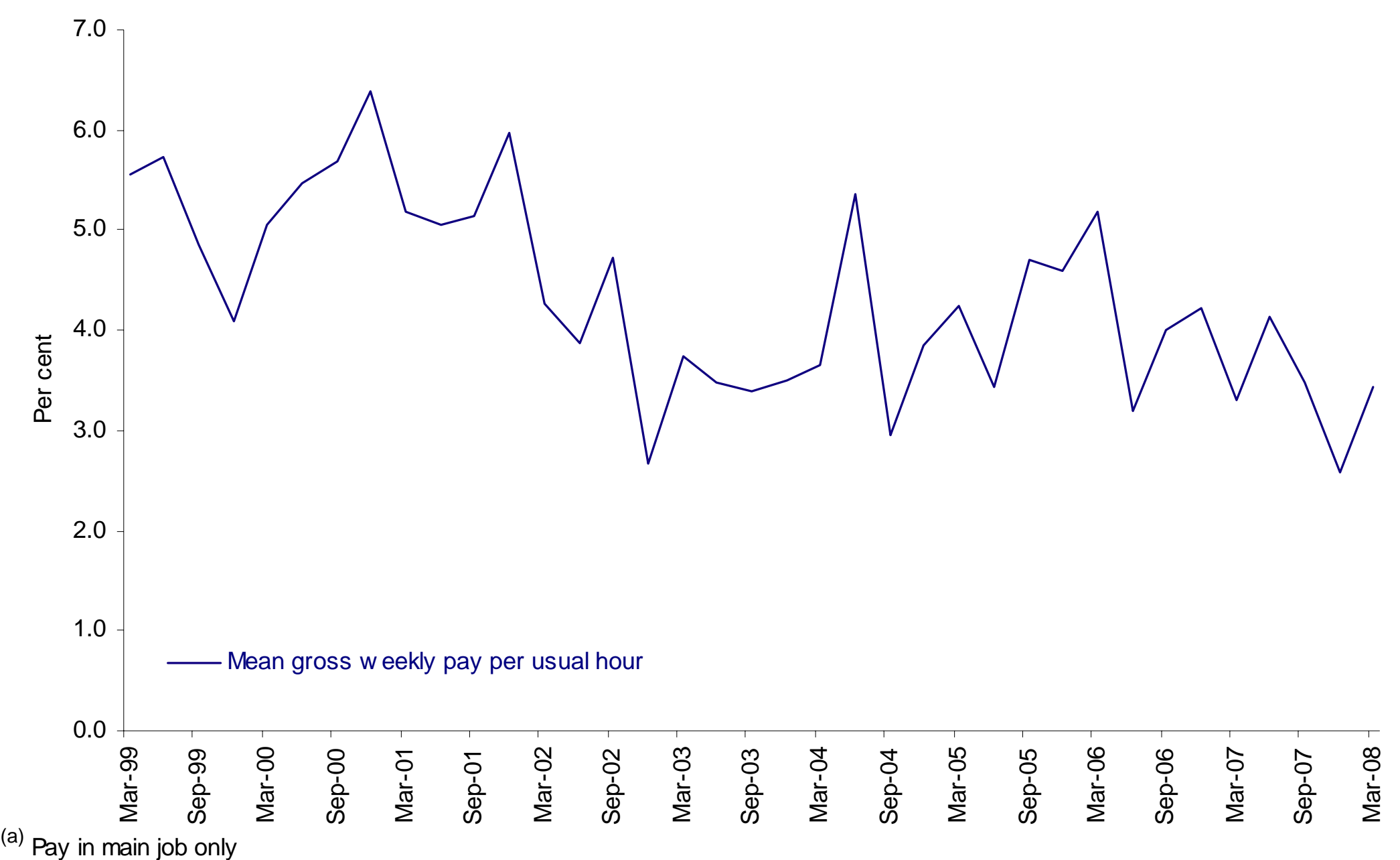

Source: LFS, Bank of England 